US Army Corps of Engineers ${ }_{\circledast}$

Engineer Research and Development Center

Aquatic Plant Control Research Program

Possible Impact of Lake Seminole Hydrilla by the Introduced Leaf-Mining Fly Hydrellia pakistanae

Michael J. Grodowitz, Alfred F. Cofrancesco,

Robert M. Stewart, John Madsen, and Don Morgan
September 2003 


\section{Possible Impact of Lake Seminole Hydrilla by the Introduced Leaf-Mining Fly Hydrellia pakistanae}

Michael J. Grodowitz, Alfred F. Cofrancesco, Robert M. Stewart, and John Madsen

Environmental Laboratory

U.S. Army Engineer Research and Development Center

3909 Halls Ferry Road

Vicksburg, MS 39180-6199

Don Morgan

U.S. Army Engineer District, Mobile

Lake Seminole Project Office

Chattahoochee, FL 32324

Final report

Approved for public release; distribution is unlimited 


\begin{abstract}
Hydrellia pakistanae, a biological control agent of hydrilla, was first introduced into Lake Seminole in 1990. Impact by this species remained low until 1998 when large numbers of individuals and associated impact, as well as increases in native plant diversity, were observed in several locations. In 1999, large-scale reductions in hydrilla were observed throughout many areas of the lake. These changes were correlated with changes in insect numbers where large increases in fly populations were correlated with decreases in tuber numbers and increases in species richness. While insect numbers were reduced in 2000 , significant decreases in biomass and increases in native plant diversity were observed when numbers of immatures and/or feeding damage were high. While the evidence presented herein indicates that the flies played a major role in the hydrilla decline on Lake Seminole, other factors may have contributed to the observed reductions. This includes such obvious changes as decreases in lake levels brought on by drought that may have increased light penetration in shallower areas, thus allowing for increased growth of natives. More likely, a complex of factors, including H. pakistanae feeding damage, contributed to the observed changes in hydrilla status on Lake Seminole.
\end{abstract}

DISCLAIMER: The contents of this report are not to be used for advertising, publication, or promotional purposes. Citation of trade names does not constitute an official endorsement or approval of the use of such commercial products. All product names and trademarks cited are the property of their respective owners. The findings of this report are not to be construed as an official Department of the Army position unless so designated by other authorized documents. 


\section{Contents}

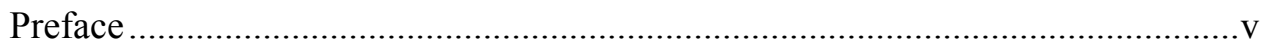

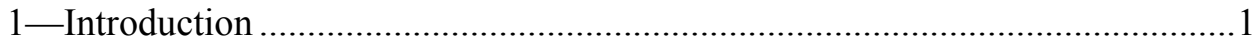

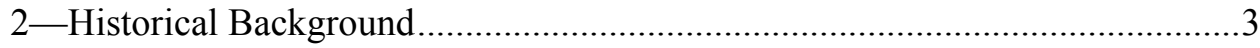

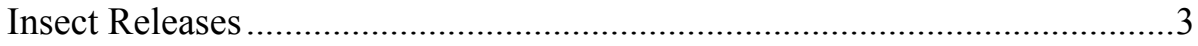

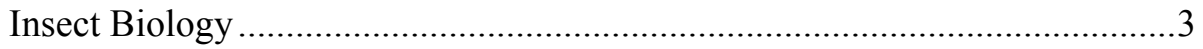

Initial Monitoring of Insect Population and Associated Damage

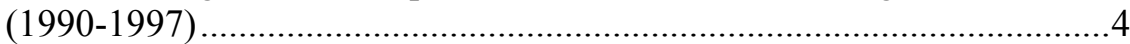

Current Monitoring of Insect Population and Associated Damage

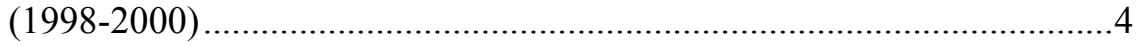

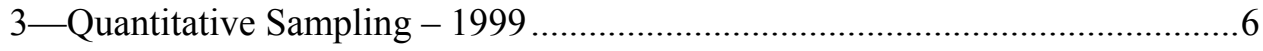

4-Quantitative Sampling - 2000 ..................................................................10

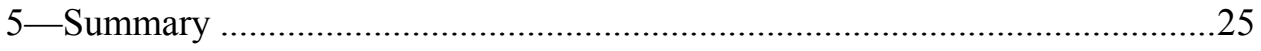

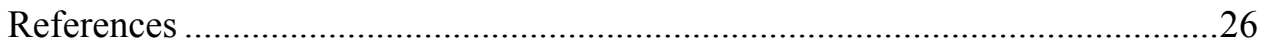

SF 298

\section{List of Figures}

Figure 1. Map of Lake Seminole with areas sampled in September 1999 and November 1999 and original release areas for H. pakistanae.

Figure 2. Hydrilla showing signs of stress as indicated by the lower number of leaves and large numbers of floating stem pieces collected from the area known as the Flats in July 1999

Figure 3. Mean number of immatures per kg of wet plant material and associated percent leaf damage for sites sampled on Lake Seminole during September 1999 and November 1999 
Figure 4. Dry shoot biomass per $\mathrm{m}^{2}$, tuber numbers per $\mathrm{m}^{2}$ basis, and species richness for Lake Seminole sites sampled November 1999 8

Figure 5. Comparisons between tuber numbers per $\mathrm{m}^{2}$ and number of plant species and percentage damaged leaves for sites sampled in September 1999

Figure 6. Number of immatures and associated percent leaf damage for each Lake Seminole site sampled in 2000. 12

Figure 7. Total hydrilla biomass dry weight and tuber numbers per $\mathrm{m}^{2}$ for all Lake Seminole sites sampled in 2000

Figure 8. Species richness or number of plant species and percent hydrilla for Lake Seminole sites sampled in 2000 ... 14

Figure 9. Leaf hardness for Lake Seminole sites sampled in 2000 15

Figure 10. Linear relationship between leaf hardness and percent protein for sites sampled on Lake Seminole during 2000

Figure 11. Percentage crude protein for Lake Seminole sites sampled in 1999

Figure 12. Percentage crude protein for all Lake Seminole sites sampled in 2000 18

Figure 13. Relationship between mean immatures per $\mathrm{kg}$ and ether extractable compounds for sites sampled on Lake Seminole during 2000

Figure 14. Statistical graphing technique using a linear and quadratic model examining the relationship between immatures per kg, percent leaf damage, hydrilla biomass, and species richness for all Lake Seminole sites sampled during 2000

Figure 15. Relationship between the percentage of stems damaged to both species richness and hydrilla biomass

Figure 16. Lake Seminole midnight pool elevations from October 1993 through September 2000

Figure 17. Correlations between depth and hydrilla biomass, species richness, tuber numbers per $\mathrm{m}^{2}$, and leaf hardness for means calculated on a species richness basis

Figure 18. Influence of depth on both immatures per $\mathrm{kg}$ and percent damaged leaves for Lake Seminole sites sampled during 2000 


\section{Preface}

The work reported herein was conducted as part of the Aquatic Plant Control Research Program (APCRP). The APCRP is sponsored by Headquarters, U.S. Army Corps of Engineers (HQUSACE), and is assigned to the U.S. Army Engineer Research and Development Center (ERDC) under the purview of the Environmental Laboratory (EL), Vicksburg, MS. Funding for the APCRP was provided under Department of Army Appropriation Number 96X3122, Construction General. Mr. Robert C. Gunkel, Jr., ERDC, EL, was Program Manager, APCRP. Technical Monitor during this study was Mr. Timothy Toplisek, HQUSACE.

The work described herein was directed by Dr. Michael Grodowitz, Aquatic Ecology and Invasive Species Branch (EE-A), Ecosystem Evaluation and Engineering Division (EE), EL, with assistance from Dr. Al Cofrancesco, Chief, EE-A; Mr. Robert M. Stewart, U.S. Army Engineer District, Vicksburg; Dr. John Madsen, faculty, Mississippi State University, Starkville, MS; and Mr. Don Morgan, Lake Seminole Project Office, U.S. Army Engineer District, Mobile, AL.

The report was reviewed internally by Dr. Judy Shearer and Ms. Chetta Owens, EE-A, EE, EL. This investigation was performed under the direct supervision of Dr. Cofrancesco and the general supervision of Dr. Dave Tazik, Chief, EE, and Dr. Elizabeth C. Fleming, Director, EL.

Commander and Executive Director of ERDC was COL James R. Rowan, EN. Director was Dr. James R. Houston. 


\section{Introduction}

Lake Seminole is a large, 1,500-hectares lake that borders both Georgia and Florida (Figure 1). The lake has over $560 \mathrm{~km}$ of shoreline and extends up the Chattahoochee River for over $50 \mathrm{~km}$ and the Flint River for approximately $60 \mathrm{~km}$. The Rivers and Harbor Act of 1947 originally authorized the Lake Seminole project as the Jim Woodruff Lock and Dam with construction completed in 1957. The three completed locks and dams on the Apalachicola, Chattahoochee, and Flint River systems provide navigation, recreation, and hydropower to the general vicinity (Gholson 1984).

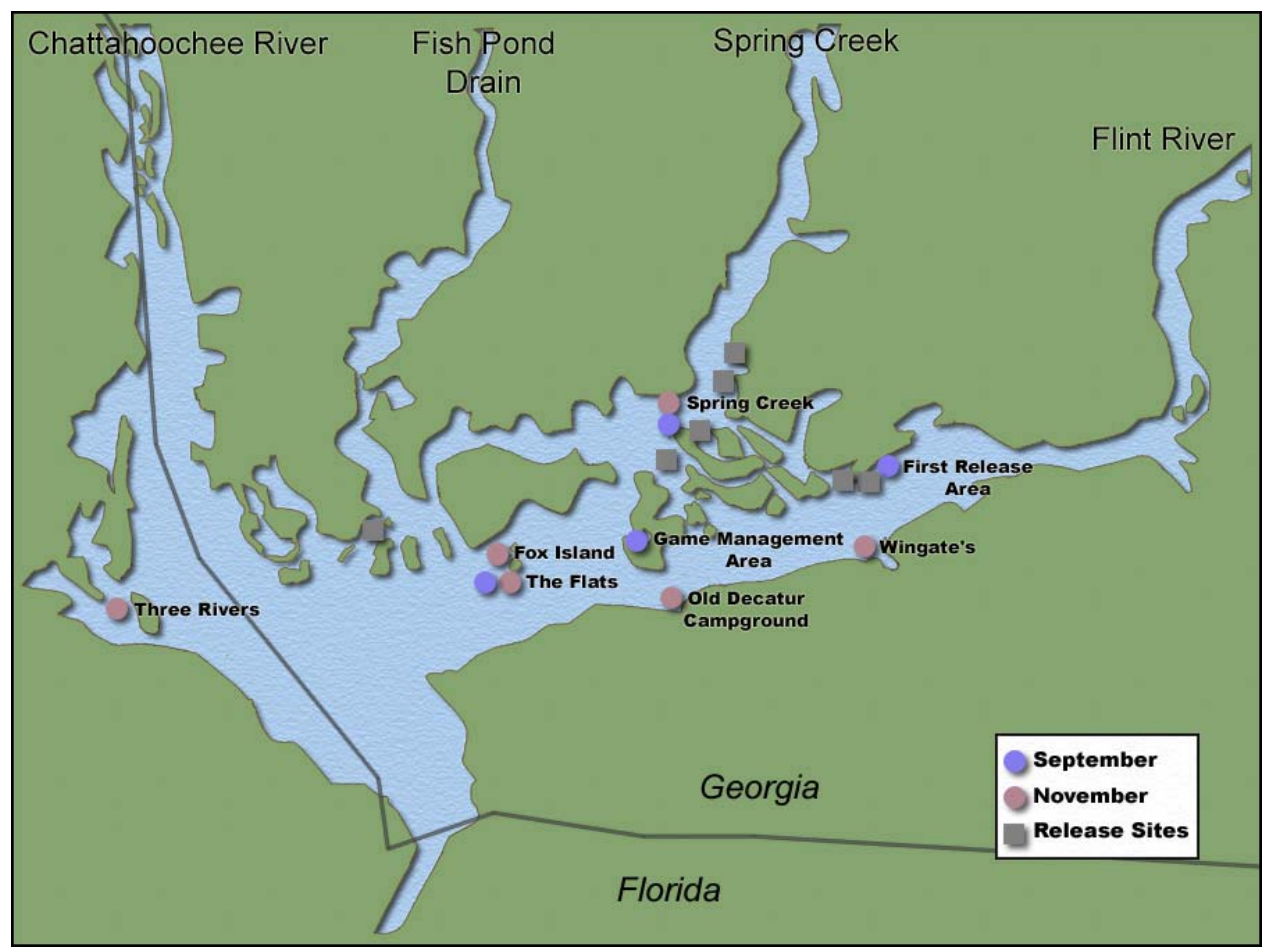

Figure 1. Map of Lake Seminole with areas sampled in September 1999 and November 1999 and original release areas for H. pakistanae

The origin of hydrilla (Hydrilla verticillata (L. f.) Royle) in Lake Seminole is unknown. It first appeared in Cypress Pond in the 1960s and, according to rumor, was planted there by a local aquarium dealer. The plant subsequently spread to Fish Pond Drain and to Spring Creek in following years. In the early 1980's, hydrilla infestations were large but typically remained in the clear areas of the 
lake with only minimal quantities found in the river sections. From the mid 1980 's to the present, hydrilla acreages have increased tremendously throughout the system especially in the Flint and Chattahoochee arms of the lake. Hydrilla, at times, has covered more than 50 percent of the lake surface (Gholson 1984).

Because of the increasing hydrilla infestations on Lake Seminole and the subsequent impacts to a wide range of water uses, researchers at the U.S. Army Engineer Research and Development Center (ERDC), Vicksburg, MS, were asked in 1989 by personnel in the U.S. Army Engineer District (USAED), Mobile, AL, to implement the use of insect biological control technologies for managing the hydrilla infestations. The first release of agents commenced in 1990.

Beginning in 1994, the USAED, Mobile, began a process that culminated in the development of the Lake Seminole Hydrilla Action Plan that was published in 1998/1999 (U.S. Army Corps of Engineers 1998). This plan outlines the available management tools for controlling hydrilla and provides detailed information on implementing these strategies as part of an overall integrated management plan. The release, establishment, and monitoring of the hydrilla leaf-mining flies is an important component of that plan.

While ERDC scientists have periodically examined Lake Seminole hydrilla for the presence of the leaf-mining flies and their associated impact to the plants, significant monitoring was not accomplished to any great extent following the last release in 1993. However, in late summer 1999, lake managers informed ERDC scientists that significant declines had and were occurring to the hydrilla in many portions of Lake Seminole. Lake managers believed the declines might be related to the presence of the flies. ERDC dispatched a team of researchers to Lake Seminole in September 1999 to examine the situation. They verified that large numbers of flies were present and were apparently impacting the plants. The researchers recommended that detailed sampling be initiated to further substantiate the cause of the hydrilla decline. The following is a summary of the findings of the initial sampling on Lake Seminole during FY 1999 and in FY 2000. 


\section{Historical Background}

\section{Insect Releases}

Beginning in 1990 and continuing through 1993, over 2,250,000 individuals of $H$. pakistanae Deonier were released at seven different locations (Figure 1) on Lake Seminole (Center et al. 1997) (Table 1). The majority of these individuals (ca. 2,000,000) were introduced into the lake from harvested plant material that was obtained from ponds located at the Tennessee Valley Authority Reservation in Muscle Shoals, AL. These ponds were used for rearing H. pakistanae as part of a large-scale project to manage hydrilla in Guntersville Reservoir (Bates et al. 1991, Grodowitz and Snoddy 1995). The remaining individuals used for release were obtained from mass-rearing operations at ERDC (Freedman and Grodowitz 2001) and the U.S. Department of Agriculture, Agricultural Research Service (USDA, ARS), Aquatic Plant Management Laboratory in Ft. Lauderdale, Florida. The majority of the released individuals were in the immature forms; however, over 3,000 adults were also introduced into several areas.

\begin{tabular}{|c|c|c|c|c|c|}
\hline \multicolumn{6}{|c|}{$\begin{array}{l}\text { Table } 1 \\
\text { Number of } H \text {. pakistanae Individuals Released on Lake Seminole } \\
\text { Beginning in } 1990 \text { and Continuing through } 1993\end{array}$} \\
\hline \multirow[b]{2}{*}{$\begin{array}{l}\text { Year (Number of } \\
\text { Releases) }\end{array}$} & \multicolumn{5}{|c|}{$\begin{array}{l}\text { Number H. pakistanae Released in Lake Seminole (after Center et al. } \\
\text { 1997) }\end{array}$} \\
\hline & $\begin{array}{l}\text { Eggs and } \\
\text { Neonates }\end{array}$ & $\begin{array}{l}\text { Late } \\
\text { Instars }\end{array}$ & Adults & $\begin{array}{l}\text { From Infested } \\
\text { Plants }\end{array}$ & Total \\
\hline $1990(21)$ & 20,110 & $\begin{array}{l}16,916 \\
\end{array}$ & 3,244 & 0 & 40,270 \\
\hline $1991(23)$ & 96,305 & 51,281 & 300 & 0 & 147,886 \\
\hline $1992(21)$ & 1,804 & 93,620 & 0 & $2,000,000$ & $2,095,424$ \\
\hline $1993(1)$ & 0 & 2,442 & 0 & 0 & 2,442 \\
\hline Total (66) & 118,219 & 164,259 & 3,544 & $2,000,000$ & $2,286,022$ \\
\hline
\end{tabular}

\section{Insect Biology}

Adult $H$. pakistanae are small flies about $2 \mathrm{~mm}$ in length, which reside almost exclusively on or near hydrilla infestations (Baloch and Sana-Ulah 1974; Buckingham et al. 1989; Center et al. 1997; USAERDC 1998). The flies resemble small gnats and appear to jump along the water surface from one resting place to another instead of actually flying. Eggs are laid on emergent aquatic vegetation, including hydrilla and areas near hydrilla infestations. Females lay eggs singly, and each female can oviposit up to 100 eggs for the length of her reproductive period. Eggs hatch in 3 to 4 days depending on temperature. When the larvae emerge from the eggs, they enter the water and crawl along stems in 
search of hydrilla. Larvae tunnel or mine hydrilla leaves, feeding and destroying about 9 to 12 leaves during three larval stages. Late third-instar larvae pierce the stem tissues with two needle-like projections and subsequently pupate. It is believed that piercing the stem allows the pupae to obtain oxygen. Pupae are housed within a protective case known as the puparium, which is formed from the hardened last larval cuticle. The pupae are roughly cigar-shaped and resemble hydrilla axillary buds. The duration of the pupal stage is from 6 to 15 days, after which the emerging adult floats to the surface in an air bubble.

\section{Initial Monitoring of Insect Population and Associated Damage (1990 - 1997)}

Insect populations at Lake Seminole were monitored periodically after the initial introductions in 1990. Early monitoring protocols were minimal, consisting mainly of in situ hand collection of adults, Berlese funnel extractions, and laboratory enumeration of adults that emerged from field collected hydrilla. While populations remained at reduced levels during the early establishment period (i.e., 1990 through 1993), adult $H$. pakistanae were routinely collected from a variety of sites, lending credence that the fly was established at Lake Seminole.

Stem collections during 1991 at two different release sites indicated the presence of $H$. pakistanae in Lake Seminole. Out of a total of 56 stems examined, over 40 percent had some signs of $H$. pakistanae leaf damage ranging from 2 to 50 percent of the leaves damaged. This indicated a tentative establishment, since releases were still continuing. Establishment is considered confirmed when adults are collected 3 to 6 months after the releases are terminated. Although established at the site after termination of releases in 1993, H. pakistanae populations remained low as measured by percent leaf damage and numbers of immatures per kilogram of wet plant weight. For example, in 1997, examination of three release sites revealed immature levels at about 50 immatures per kilogram with percent leaf damage of $<1$ percent.

Two other native insect herbivores were also routinely collected from Lake Seminole. These included the Asian Hydrilla Moth (Parapoynx diminutalis Snellen) and a complex of plant feeding chironomids in the Cricotopus sylvestris group that severely damaged hydrilla apical tips on the Lake. Damage from both of these herbivores was highly patchy and apparently had only limited impact to the hydrilla infestations.

Because of the limited increases in fly populations at Lake Seminole and at other sites around the country coupled with decreases in funding, monitoring was reduced to only periodic qualitative observations in the years following the last introductions in 1993.

\section{Current Monitoring of Insect Population and Associated Damage (1998 - 2000)}

Lake Seminole was again visited in May 1998. Major qualitative changes to the plant assemblages were observed at several areas of the Lake with apparent 
decreases in hydrilla infestations and associated increases in native plant communities. One site where this was particularly evident was Cummin's Landing where 2,000,000 H. pakistanae immatures were released using harvested plant material in 1992. Lake managers indicated that reasons for the hydrilla declines were unknown but were not related to grass carp feeding activity or abiotic stresses. This site historically had almost a 100 -percent hydrilla surface coverage. However, during the May 1998 visit, it was apparent that several species of pondweeds and American Lotus now occupied large areas previously colonized by hydrilla. Visual inspection of hydrilla stems revealed H. pakistanae larval damage in about 95 percent of the stems collected at random with many stems having near 35 percent or higher of the leaves damaged. Such a large population of $H$. pakistanae during the early part of the growing season indicated that insect populations had and were reaching levels not observed previously at Lake Seminole or at many other release sites across the country.

In July 1999, Lake Seminole managers again contacted ERDC researchers to report that striking changes in the hydrilla were occurring in several areas of the Lake, most notably the area called the Flats located across from the Flint River from River Junction south of the Duck Refuge (Figure 1). The area in question was about $80,940 \mathrm{~m}^{2}$ (20 acres) in size and had large areas where "holes" had developed in the mat, hydrilla plants had decreased that number of leaves, and large numbers of broken floating stem pieces were noted on the water surface (Figure 2). Reasons for such changes were unknown but lake managers identified Hydrellia spp. larvae in the leaf tissues, which led them to believe that the flies were wholly or partially responsible for the observed changes.

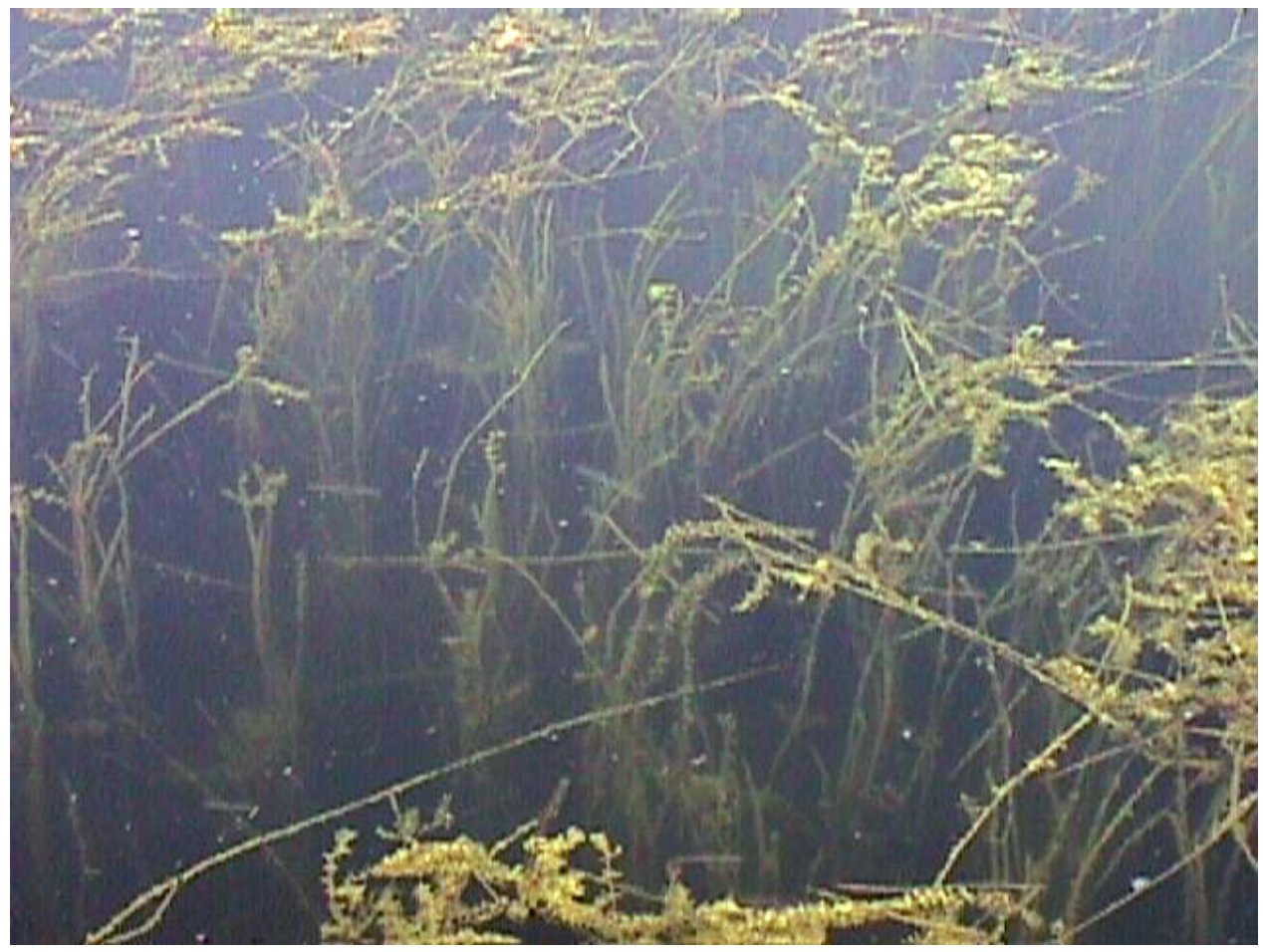

Figure 2. Hydrilla showing signs of stress as indicated by the lower number of leaves and large numbers of floating stem pieces collected from the area known as the Flats in July 1999 


\section{Quantitative Sampling - 1999}

In September 1999, researchers from ERDC quantitatively examined four sites (Figure 1) on the Lake for immatures and associated damage. Hydrilla was also qualitatively assessed. Sites included Spring Creek (SprCrk), the area first used for fly releases (FirstRel), the Game and Fish Management Area (G\&FMA), and the Flats (Figure 1). The number of immatures in these areas was high, ranging in September 1999 from about 1,000 immatures per kilogram wet plant material in G\&FMA to over 2,700 immatures per kilogram in the Flats (Figure 3). Leaf damage roughly paralleled immature numbers with values ranging from 10 percent to over 16 percent of the leaves damaged. While adults were not quantitatively evaluated, adult levels were extremely high with large numbers observed covering the boat and the remaining hydrilla mats. The numbers of adults were so substantial that the ERDC scientists returned to the site in October 1999. Two members of the staff working for 3 days easily collected over 50,000 adults to be introduced in the upper reaches of the Chattahoochee River where H. pakistanae had never been released.

Hydrilla was obviously stressed and declining in large areas of the sites examined and in many instances former hydrilla monocultures were now mixed species assemblages dominated by Najas spp., Nelumbo lutea (Willd.) Pers., and Potamogeton spp. In addition, large numbers of floating stem pieces indicative of $H$. pakistanae feeding were observed in areas with higher fly populations (Grodowitz et al. 1999).

With the high numbers of flies observed in September and obvious changes in hydrilla status, a detailed insect and plant sampling was initiated in November 1999. Six sites were selected, including Spring Creek (SprCrk) and the Flats (Flats), which corresponded to sites sampled in September 1999, as well as Three Rivers (ThreeRiv), the Decatur Campground area (Camp), Wingates (Wingates), and Fox Island (FoxIsl), that were not sampled in September (Figure 1).

Wingates and Three Rivers served as controls and were selected because they appeared to have negligible fly damage, and the hydrilla in these areas was only minimally stressed and appeared mainly as a monoculture. The hydrilla at the Wingate site was treated with Sonar within the last few years and was now growing with renewed vigor. The herbicide treatment could have negatively impacted insect levels at this site by the removal of plant material thereby indirectly inducing high mortality in the immature stages. This could explain the obviously healthy hydrilla in this area compared to other locations on the Lake. 
Such indirect herbicide effects have been documented previously for insect agents associated with waterhyacinth (Grodowitz and Pellessier 1989,

Cofrancesco and Pellessier 1988, Haag 1986a, 1986b). The ThreeRiv site was far removed from the initial insect releases and insect numbers have remained low in this area based on minimal surveying accomplished at this site and in adjacent areas in the past.

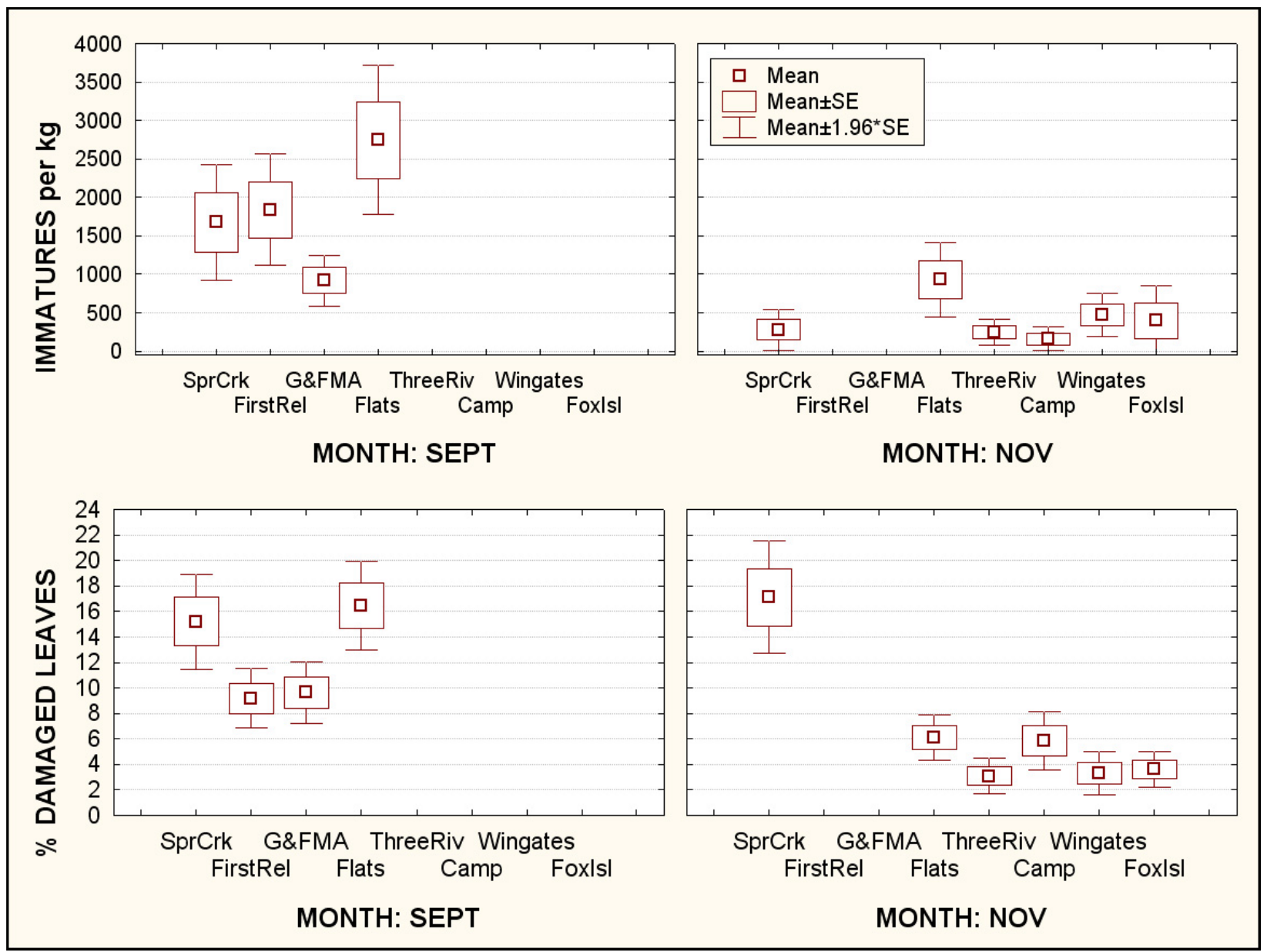

Figure 3. Mean number of immatures per kg of wet plant material and associated percent leaf damage for sites sampled on Lake Seminole during September 1999 and November 1999

For each of these sites, immature numbers and associated percent leaf damage were quantified (Figure 3 ). In addition, plant biomass and tuber numbers were determined, based on twelve $1 / 10 \mathrm{~m}^{2}$ samples per site (Figure 4). In addition, species richness (i.e., number of plant species) was quantified for each sample (Figure 4).

Immature numbers per kilogram decreased 6 fold and $<3$ fold, respectively, in SprCrk and the Flats from the September to November sampling in 1999 (Figure 3). The percent of damaged leaves was variable at the two sites, ranging from a 2.5-fold decrease for the Flats and a 2-percent increase at SprCrk. The reductions in insect numbers are not surprising, especially considering that temperatures were decreasing and day length was becoming shorter. In addition, 
hydrilla infestations had by this time decreased substantially in many areas.

Areas that were once large contiguous mats of hydrilla were now open water with only small numbers of areas containing hydrilla with full canopies. Hence, oviposition and larval feeding areas were reduced which would also contribute to decreased insect levels during the November 1999 sampling.
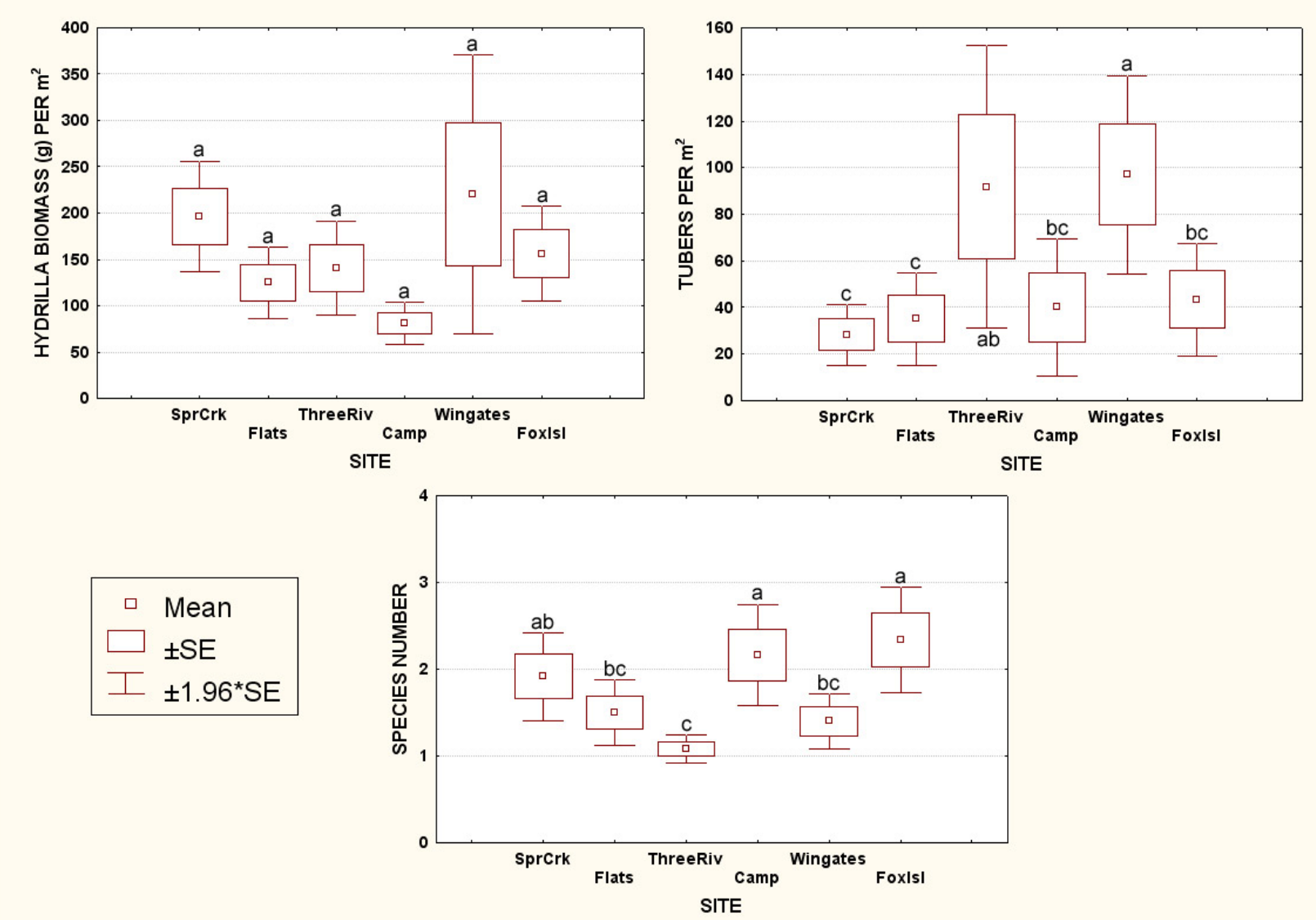

Figure 4. Dry shoot biomass per $\mathrm{m}^{2}$, tuber numbers per $\mathrm{m}^{2}$ basis, and species richness for Lake Seminole sites sampled November 1999. Means with the same letter are not significantly different at $p>0.05$

Mean shoot biomass per square meter was not significantly different for any site, although means differed almost three-fold $(\mathrm{F}=2.001, \mathrm{df}=5,64, \mathrm{p}=0.0903$; Figure 4). Plant biomass ranged from about $80 \mathrm{~g}$ per $\mathrm{m}^{2}$ for the Camp site to about $225 \mathrm{~g}$ per $\mathrm{m}^{2}$ for Wingates.

Significant differences were detected for tuber number per square meter ( $\mathrm{f}=$ $2.772, \mathrm{df}=5,64, \mathrm{p}=0.250$; Figure 4$)$. Highest tuber number per square meter occurred for the ThreeRiv and Wingates sites at about 90 tubers per $\mathrm{m}^{2}$. The remaining sites were all at least 2 fold lower. Generally, just the opposite occurred for species number (Figure 5). Sites such as Camp and FoxIsl had varying mixtures of Najas spp. and Potamogeton spp. as well as minimal numbers of other less common species. In contrast, sites such as Wingates and 
ThreeRiv where tuber numbers were high were dominated by a single species, hydrilla. The relationship between tuber numbers and number of species was even more pronounced when examining mean number of tubers for each category of species richness; i.e., 1, 2, 3, etc. (Figure 5). Highest numbers of tubers were associated with areas of low species richness. In addition, an exponential growth model between tuber numbers and percent damaged leaves explained over 80 percent of the variation in tuber numbers at different sites (Figure 5). Highest tuber numbers were associated with sites with the lowest number of damaged leaves.

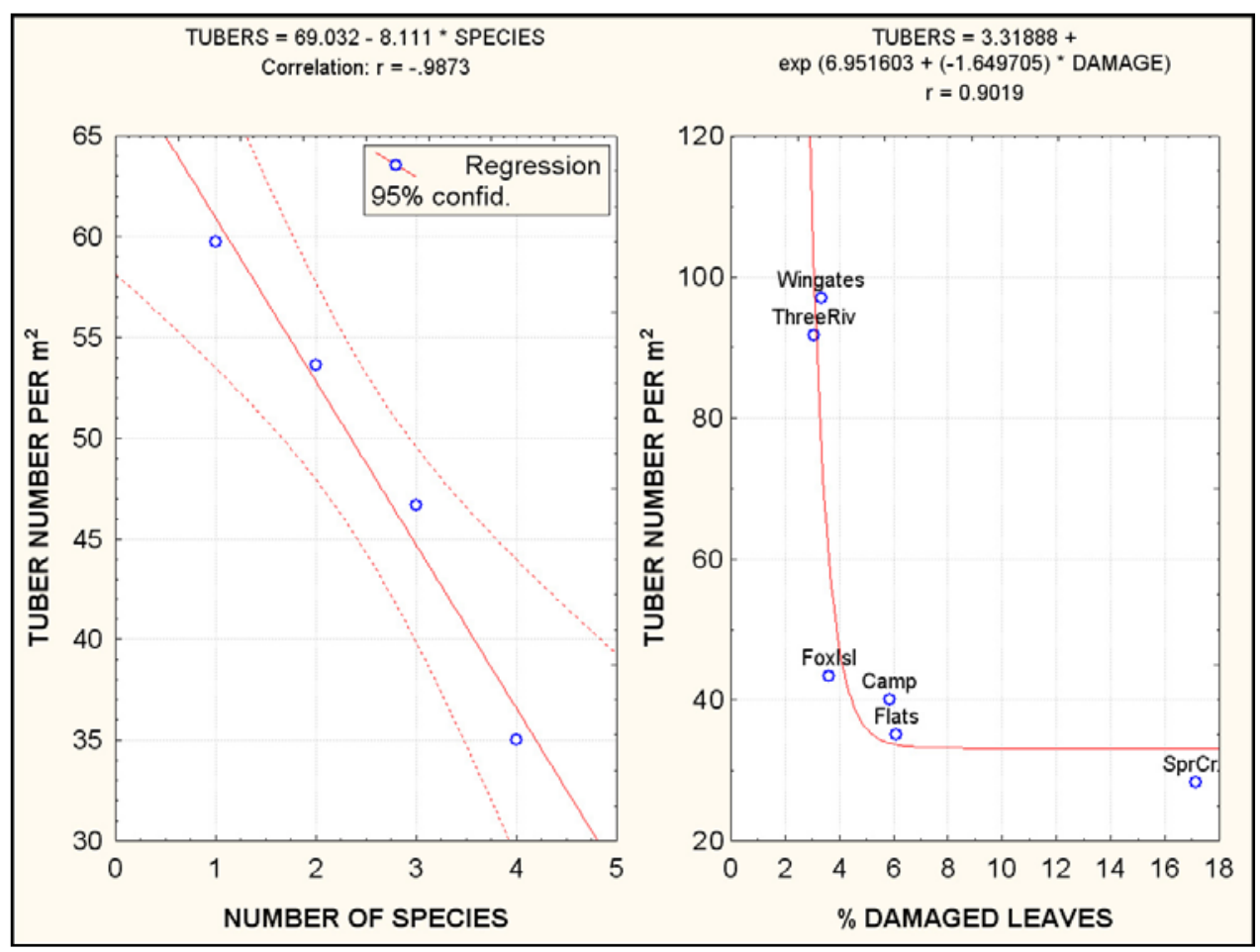

Figure 5. Comparisons between tuber numbers per $\mathrm{m}^{2}$ and number of plant species and percentage damaged leaves for sites sampled in September 1999

Decreases in tuber number due to Hydrellia spp. feeding may seem surprising, especially since it has not been reported previously by researchers examining such effects under moderate fly feeding and controlled conditions (Van et al. 1998 and Wheeler and Center 2001). However, in recently completed, large-scale, long-term tank studies, modest levels of $H$. pakistanae damage significantly reduced tuber numbers by about 20 percent and biomass by 50 percent (Doyle et al. 2003). Lower levels of stress applied over the long term may have cumulative effects on the plant that is manifested in reduced production and decreased numbers of propagules. In addition, tuber number and tuber mass, as an indication of tuber vigor, were substantially reduced even under short growing periods and only moderate damage in other recently completed studies (Doyle et al. 2002). In these experiments, relative to controls, tuber numbers were reduced by 55 percent under the highest level of herbivory. In addition, the average mass per tuber was about 60 percent less under high herbivory relative to controls at the time of harvest. 


\section{Quantitative Sampling - 2000}

Because of the dramatic increases in H. pakistanae and their possible impact to hydrilla in many areas of Lake Seminole during 1999, more quantitative sampling was initiated for 2000. This included sampling for hydrilla biomass, species richness, tuber numbers, plant nutritional composition, insect numbers, and associated damage. Sampling was conducted for 3 months (i.e., May, July, and September) at three different locations. Locations or subsites included an area adjacent to the original "Flats" area, the original Decatur Campground (Camp), and the original Three Rivers (ThreeRiv) sites. Both the Camp and ThreeRiv sites corresponded directly with those sampled during November 1999. However, the new Flats site differed from the original because of possible impact to the original Flats area due to the release of fluridone in the upper reaches of Spring Creek during 2000 for hydrilla control.

For each sampling date and site, fifteen $1 / 10-\mathrm{m}^{2}$ samples were collected randomly. From each sample, total biomass of each plant species was quantified, and $25 \mathrm{stems}, 10$ to $30 \mathrm{~cm}$ in length, were selected at random for determination of insect numbers and damage. In addition, core sediment samples were taken randomly and used to quantify total number of tubers. Various nutritional components including ash, crude protein, crude fiber, nitrogen free extract, and either extractable compounds were measured using a standard feed analysis known as a Proximate Analysis. Procedures are given in Grodowitz and McFarland (2002). However, discussions will be limited mainly to relationships for both protein and ether extractable compounds. Leaf hardness was also quantified using an in-house designed penetrometer. The device utilized a $250-\mathrm{g}$ load cell connected to a small electronic data logger. Since the load cell was designated linear, it was calibrated using two points, $0 \mathrm{~g}$ and $200 \mathrm{~g}$, achieved by using a standard calibration 200 -g weight. Randomly selected leaves were punctured with a $0.2206-\mathrm{mm}^{2}$ blunt metal probe, and the highest force required to puncture the leaf was recorded. Values were expressed on a per square millimeter basis by dividing the recorded force $(\mathrm{g})$ by the probe diameter.

Overall, fly numbers and associated damage decreased substantially from that observed in 1999 (Figure 6). For example, highest immature numbers (ca. 225 immatures/kilogram) and damage (3.8 percent) occurred at the Decatur Campground (Camp) site during September 2000 (Figure 6). This is almost 4 fold lower than what was observed during this same time period in 1999 for the 
G\&FMA; i.e., the site with the lowest recorded number of immatures during September 1999 (Figure 3). While insect numbers were suppressed compared to those observed in 1999, generally, insect numbers and associated damage increased at all sites during the later part of the year 2000 growing season with highest numbers observed during September 2000.

Reasons for declines in insect numbers and associated leaf damage are unknown. However, with the high insect numbers observed during 1999, changes in plant quality due to heavy feeding may have impacted the insect population. Similar situations have been observed at small pond facilities in Muscle Shoals, AL, and Lewisville, TX, in that $H$. pakistanae numbers declined substantially in ponds after significant damage occurred the previous growing season (unpublished data).

With insect numbers and damage being substantially lower in 2000 we expected and observed no major differences in mean plant biomass or tuber numbers (Figure 7), or species richness at any of the sites sampled relative to the sites sampled in 1999 (Figure 8). However, no direct comparisons could be made since the only quantitative plant data collected for 1999 was for November and the last biomass sample collected during 2000 was in September.

In general, highest biomass was recorded for both the Flats and ThreeRiv sites, and all sites exhibited peak values during July 2000. In addition, a general decrease in tuber numbers was observed over the entire growing season for both the Flats and Camp sites, with increases in September 2000 observed for ThreeRiv only. Overall highest number of tubers occurred at the ThreeRiv site.

Plant species richness (or number of plant species) remained relatively similar for both the ThreeRiv and Flats sites for the entire sampling period (Figure 8), but differences were noted for the Camp site. For both ThreeRiv and Flats, the number of species present averaged about 1.5 , indicating a relatively stable monoculture consisting mainly of hydrilla. Mean species richness for the Camp site, however, was higher overall relative to both the ThreeRiv and Flats sites averaging close to three plant species throughout the sampling period.

The percentage of hydrilla found at each site substantiates the differences observed in species richness (Figure 8). For example, the ThreeRiv site was strictly a hydrilla monoculture as evidenced by mean percent hydrilla values of near 100 percent. However, percentage hydrilla for the Camp site was significantly lower averaging only about 75 percent. While significant differences were not observed through time, mean number of plant species for the Camp site exhibited a discernible increase with highest values occurring in September 2000. It is interesting to note that in addition to higher species richness values, the Camp site had the highest number of immatures and associated damage when sampling was terminated in September 2000 (Figure 6). 


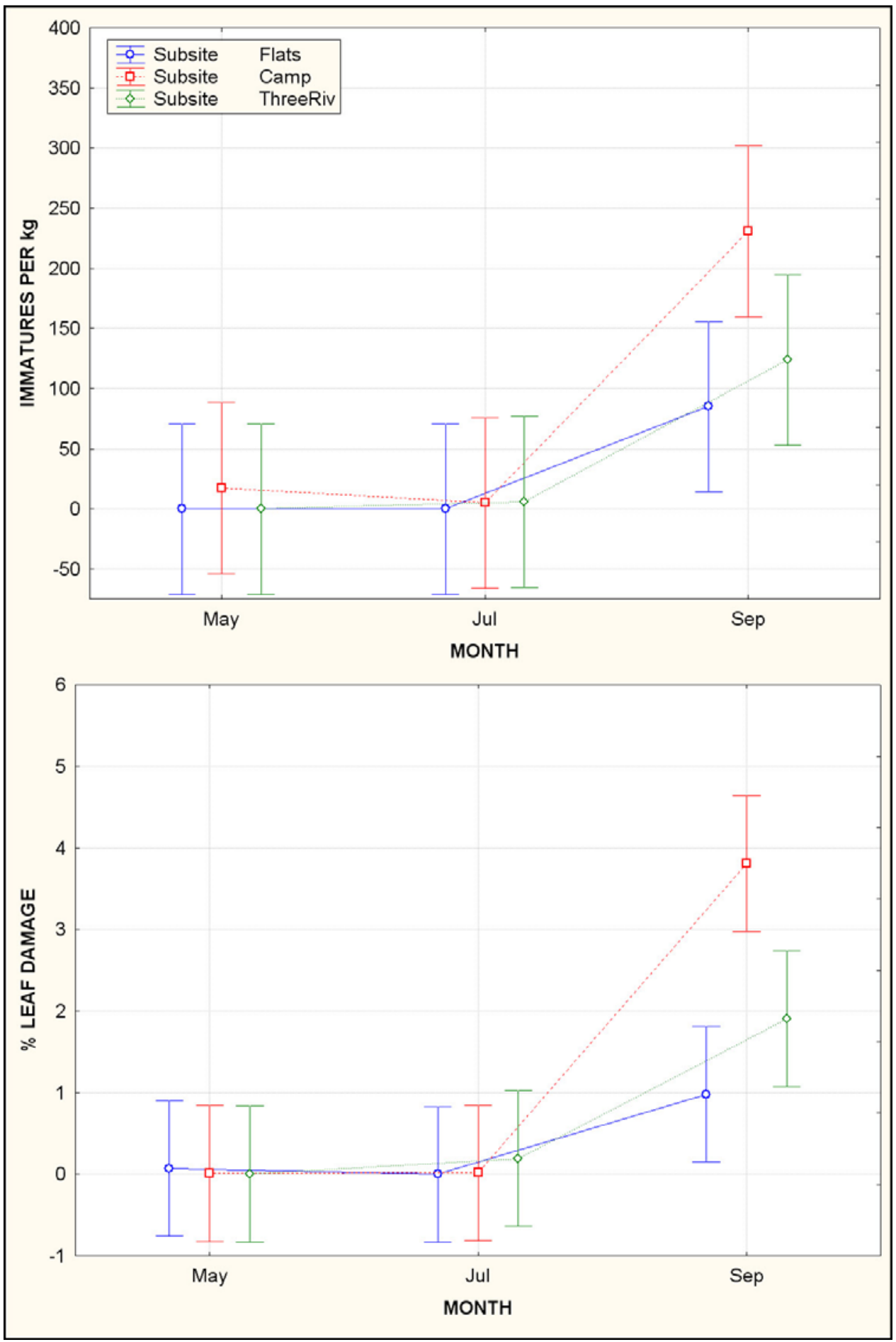

Figure 6. Number of immatures and associated percent leaf damage for each Lake Seminole site sampled in 2000. Bars surrounding the means are the $95 \%$ confidence interval based on the analysis of variance (ANOVA) error terms. ANOVA results for immatures include: Site $-\mathrm{F}$ $=1.99, \mathrm{df}=2,81, \mathrm{p}=0.1430$; Month $-\mathrm{F}=15.80, \mathrm{df}=2,81, \mathrm{p}<$ 0.0000 ; site by month interaction $-F=1.29$, df $=4,81, p=0.28$. ANOVA results for $\%$ leaf damage: Site $-F=3.79$, df, 2, 81, $p=$ 0.027 ; Month $-F=27.31$, df $=2,81, p=0.0045$; Site by Month interaction $-F=4.09, \mathrm{df}=4,81, p=0.0045$ 


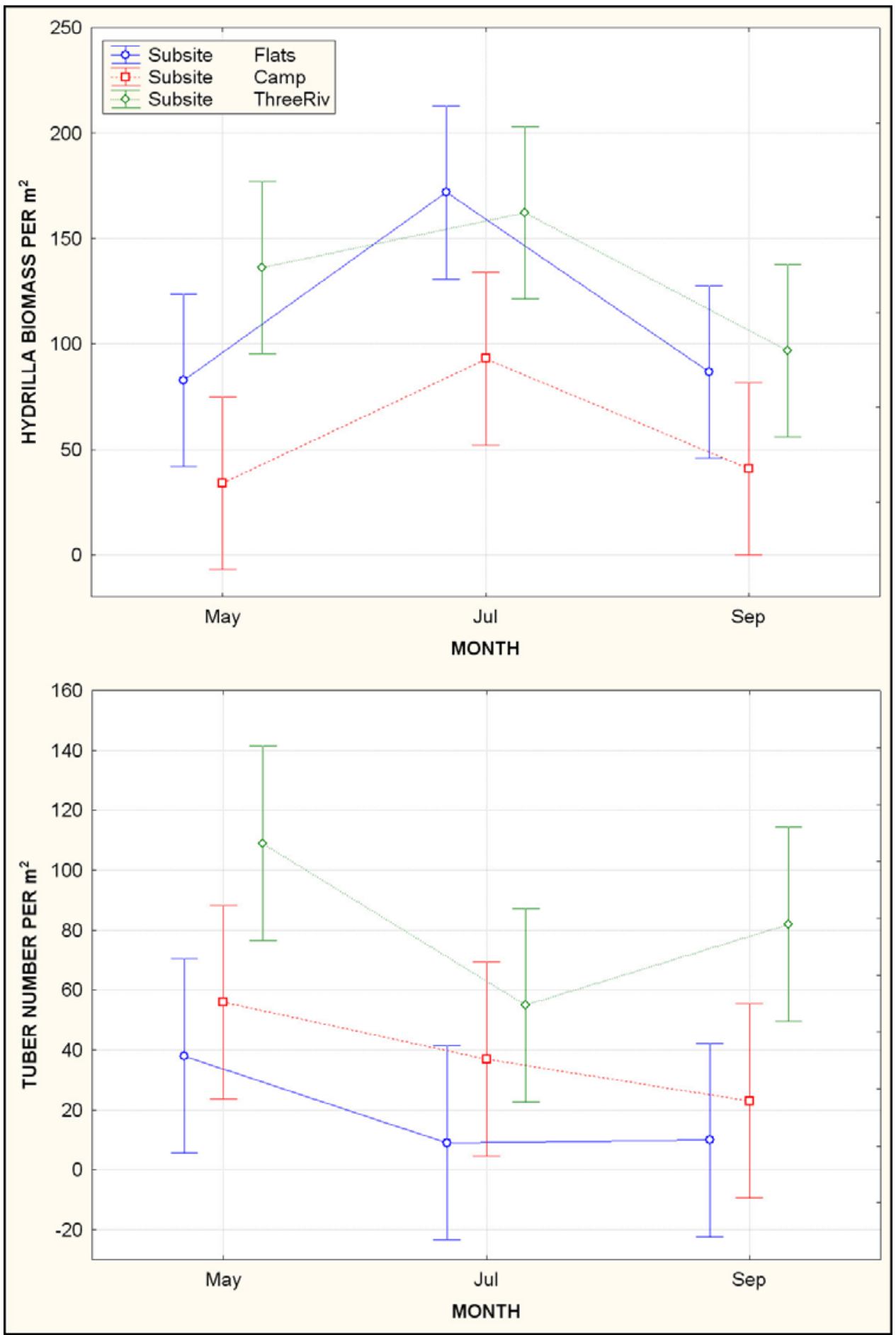

Figure 7. Total hydrilla biomass dry weight $\left(\mathrm{g} / \mathrm{mm}^{2}\right)$ and tuber numbers per $\mathrm{m}^{2}$ for all Lake Seminole sites sampled in 2000. Bars surrounding the means are the $95 \%$ confidence interval based on the ANOVA error terms. ANOVA results for hydrilla biomass include: Site $-F=11.13$, $\mathrm{df}=2,81, \mathrm{p}<0.0000$; Month $-\mathrm{F}=9.51, \mathrm{df}=2,81, \mathrm{p}=0.0002$; site by month interaction $=F=0.77, \mathrm{df}=4,81, \mathrm{p}=0.5457$. ANOVA results for tuber numbers include: Site $-F=11.75, \mathrm{df}=2,81, p<0.0000$; Month $-F=3.84, d f=2,81, p=0.0254$, Site by Month interaction $F=0.48, d f=4,81, p=0.7494$ 


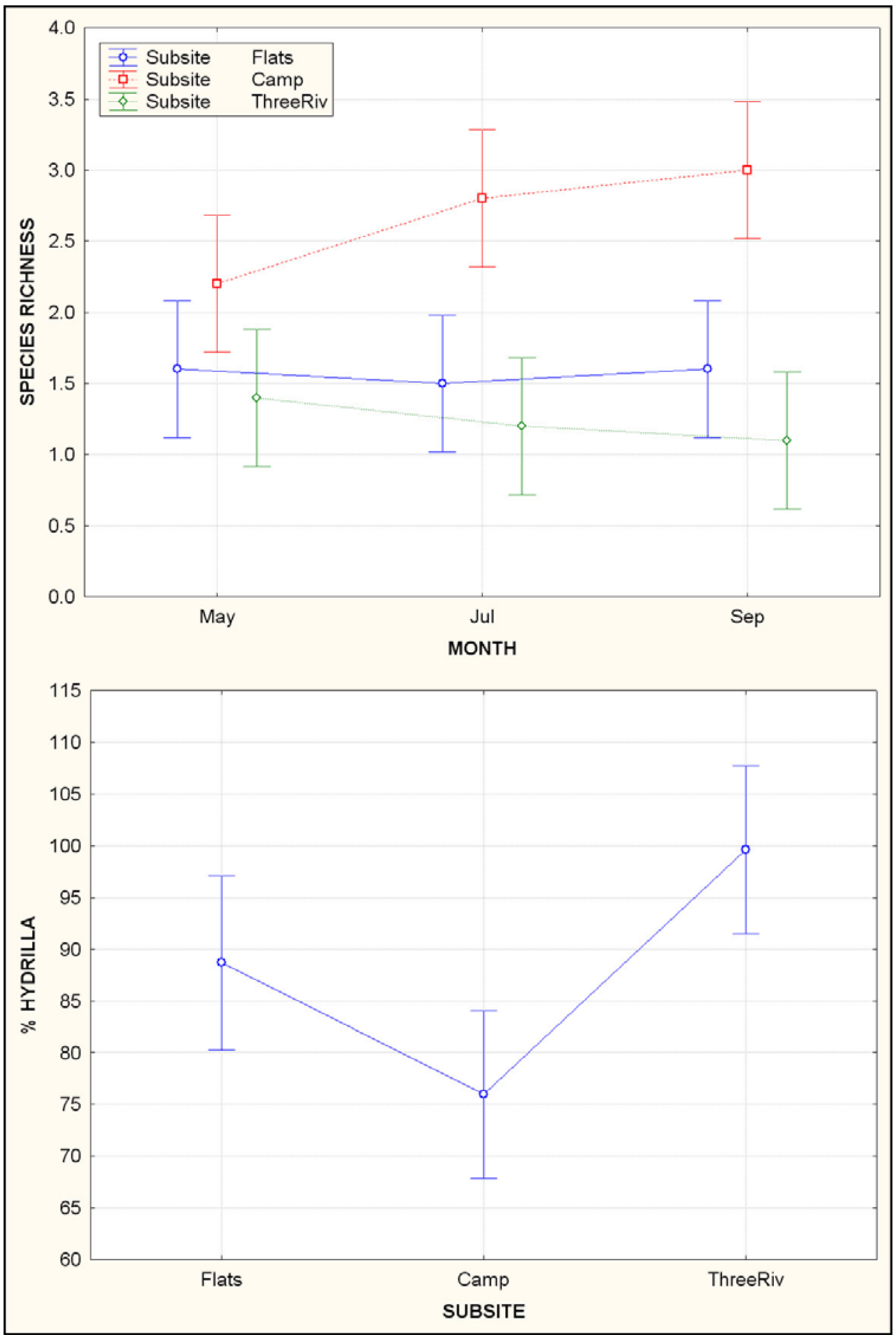

Figure 8. Species richness or number of plant species and percent hydrilla for Lake Seminole sites sampled in 2000. Bars surrounding the means are the $95 \%$ confidence interval based on the ANOVA error terms. Note that these represent a pooled mean for all months within a given site. ANOVA results for species richness include: Site $-F=28.84, d f=2,81, p<$ 0.0000 ; Month $-\mathrm{F}=0.36, \mathrm{df}=2,81, \mathrm{p}=0.6983$; site by month interaction $-F=1.53, \mathrm{df}=4,81, p=0.2017$. ANOVA results for $\%$ hydrilla include: Site $-F=8.44, d f=2,79, p<0.0005$; Month $-F=$ $0.268, \mathrm{df}=2,79, \mathrm{p}=0.7656$; site by month interaction $-\mathrm{F}=0.307, \mathrm{df}=$ $4,79, p=0.8726$ 
Leaf hardness values exhibited a decreasing trend throughout the growing season and for all sites (Figure 9). Hardness ranged from 40 to over $70 \mathrm{~g} / \mathrm{mm}^{2}$ for sites sampled in June 2000. These values decreased about 2 fold for the same sites sampled in September 2000. Reasons for decreases in leaf hardness throughout the growing season are unknown but may be related to changes in nutritional composition and/or maturity of the plant. Recent research under more controlled greenhouse/laboratory conditions have failed to produce plants with differences in leaf hardness (unpublished data). Leaf hardness values were examined because previous researchers indicated that hardness was a factor in determining larval developmental time with harder leaf values being associated with lower plant nitrogen and longer developmental times (Wheeler and Center 1996).

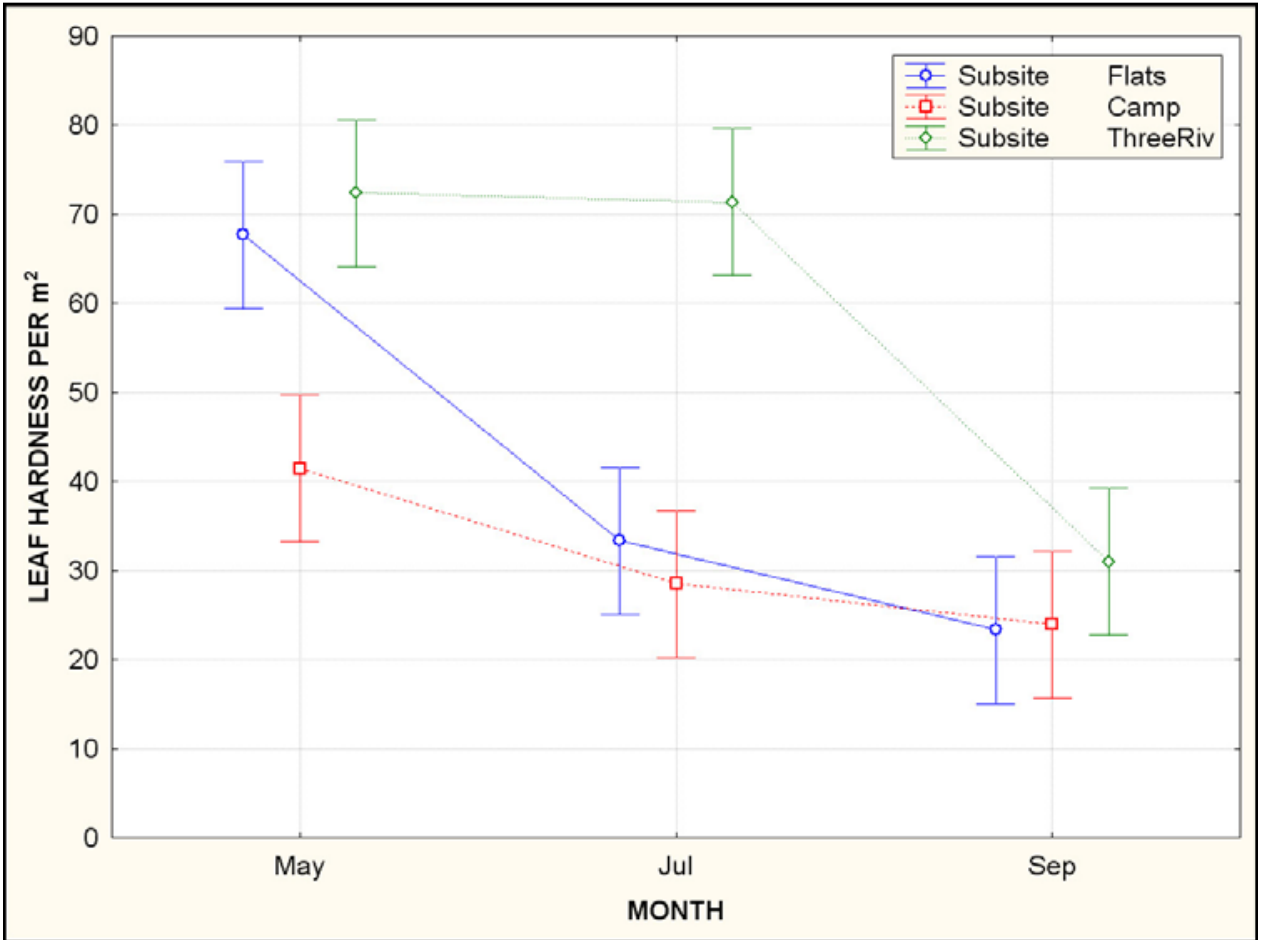

Figure 9. Leaf hardness for Lake Seminole sites sampled in 2000. Bars surrounding means are $95 \%$ confidence intervals based on ANOVA error terms. ANOVA results for leaf hardness include: Site $-F=$ 32.22, $\mathrm{df}=2,81, \mathrm{p}<0.0000$; Month $-\mathrm{F}=51.69$, df $=2,81, \mathrm{p}<$ 0.0000 ; Site by Month interaction $-F=8.45$, $d f=4,81, p<0.0000$

In this study, a significant but weak relationship existed between percent protein and leaf hardness values (Figure 10). In this case, higher protein values were associated with lower leaf hardness. This relationship was significant at the $\mathrm{p}<0.05$ but only about 47 percent of the variation was explained (i.e., $r=-0.47$ ) Percent crude protein differed significantly between sites and sampling date (Figures 11 and 12). For example, sites sampled in September 1999 exhibited protein values ranging from 11 percent to over 24 percent and all decreased significantly with the exception of SprCrk in November 1999 only varying from 
8 percent to approximately 14 percent. Highest protein values in 2000 occurred consistently for the Camp site with peak values of almost 20 percent noted for the July sampling period. Lower values occurred for the remaining two sites with peaks occurring during July 2000 for the Flats sites. One would expect that protein would influence insect levels and possibly associated damage (Wheeler and Center 1996), however, no significant relationships were found between any insect parameter and protein values.

However, a highly significant relationship between insect numbers and percent ether extractable compounds was observed when examining sites sampled in September 2000 (Figure 13). In this case, samples containing higher amounts of ether extractable compounds (i.e., mainly lipids) contained lower numbers of immatures. Very little information is available describing changes in lipid concentrations in hydrilla and even less has been reported on their impact on Hydrellia spp. larvae. However, ether extractable compounds have been implicated as influencing insect gustatory responses and feeding initiation and termination and may serve a similar role in this case (Chapman 1982). More research is warranted.

Even though insect numbers and associated damage were significantly decreased in 2000 as compared to the high numbers and leaf damage percentages observed in 1999, there were still indications that $H$. pakistanae herbivory was impacting the hydrilla. For example, based on a three-dimensional (3-D) quadratic surface plot analysis, hydrilla biomass was reduced in those samples containing higher numbers of immatures and associated leaf damage (Figure 14). This decrease was quite large with reductions in biomass approaching 10 fold. Interestingly, species richness was higher in samples containing high numbers of immatures, or high damage, or both (Figure 14). In this case, reductions were close to 2 fold. Hence, even at low overall insect impact it appears as if the hydrilla was still being affected in certain areas. 


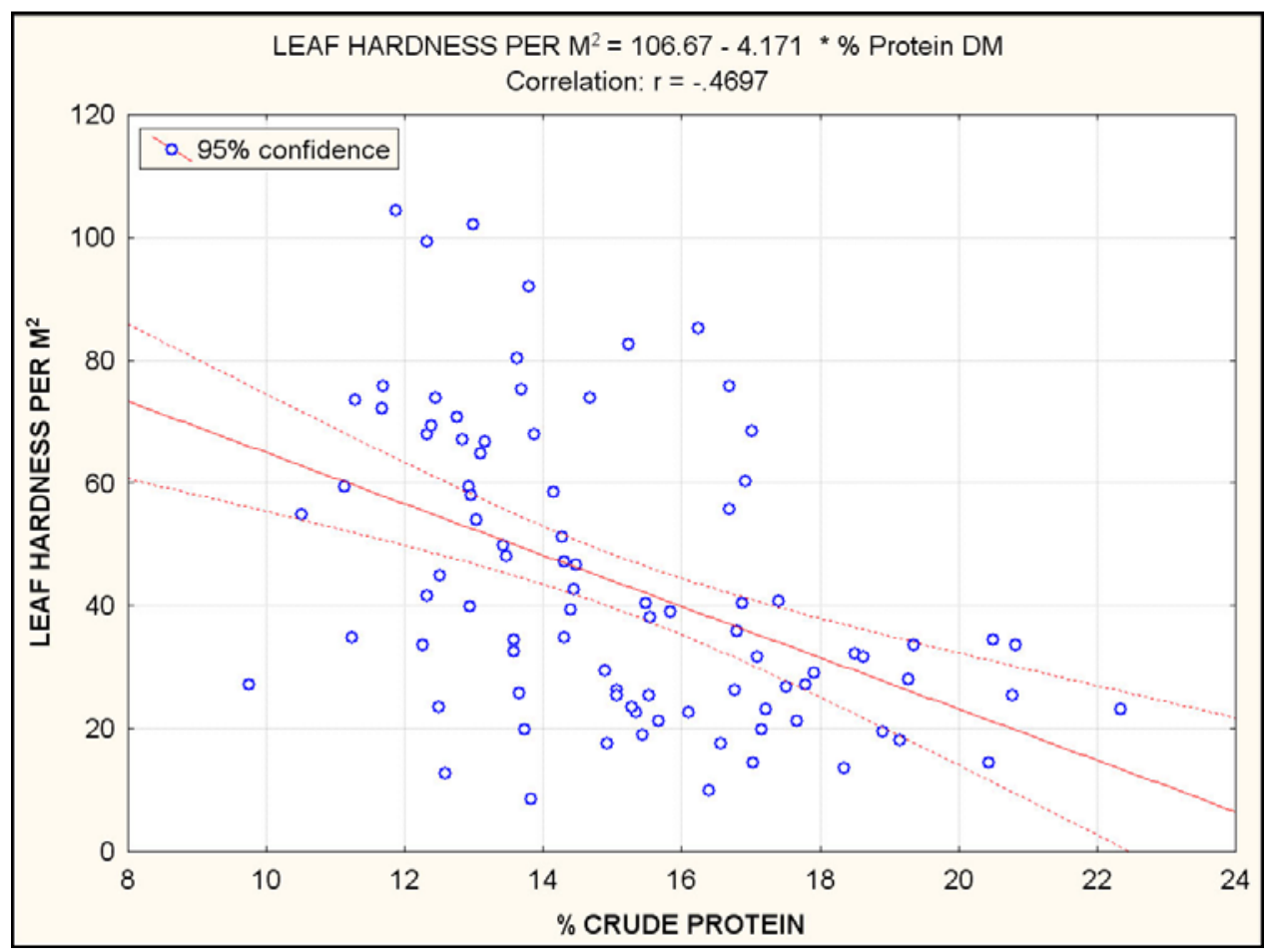

Figure 10. Linear relationship between leaf hardness and \% protein (dry matter basis) for sites sampled on Lake Seminole during $2000(p<0.05, n=90$, $r=-0.4697)$

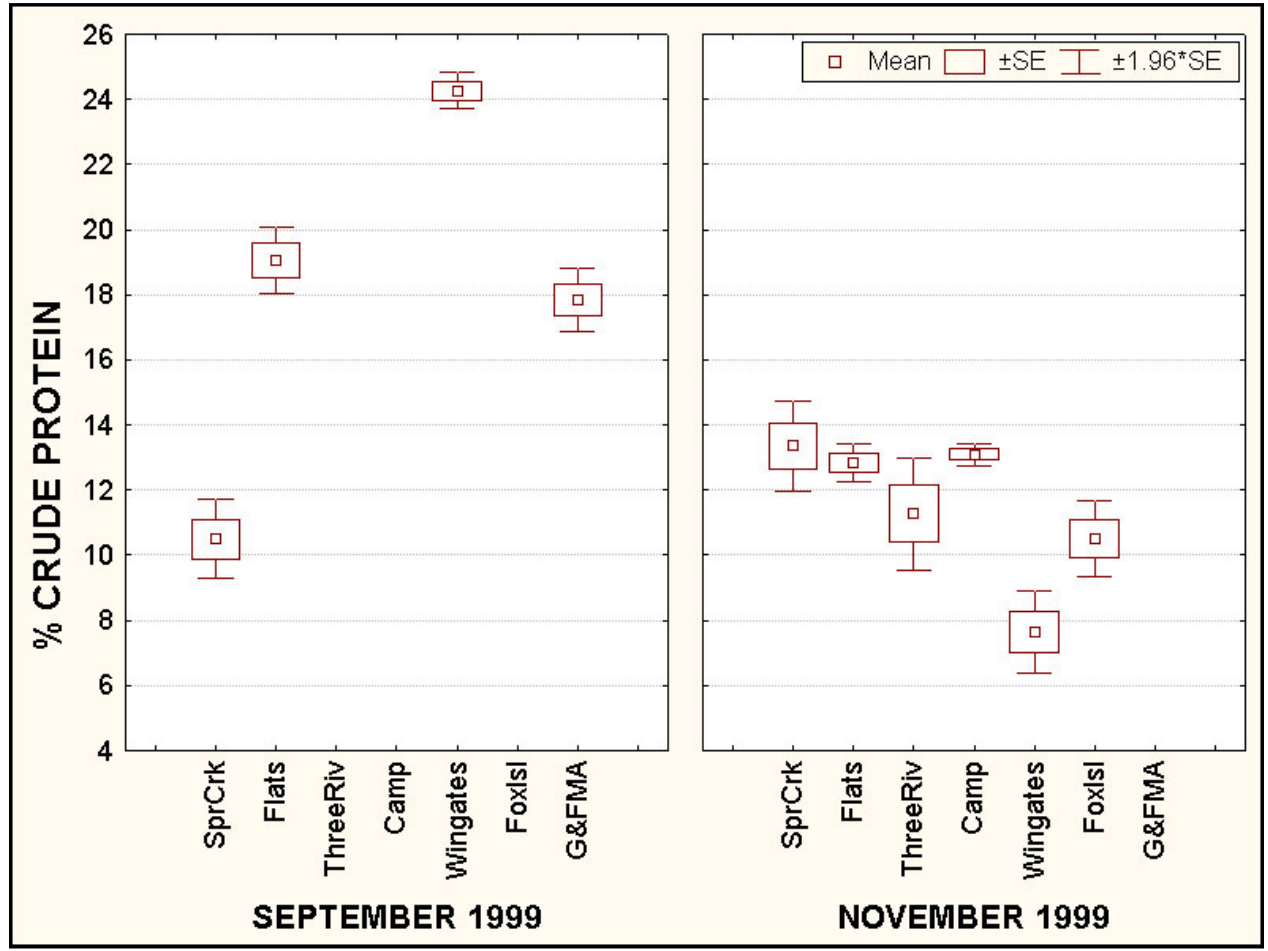

Figure 11. Percentage crude protein (dry matter basis) for Lake Seminole sites sampled in 1999. ANOVA results are given within a given sampling month since sites and sampling methods differed for each sampling period. ANOVA results for \% crude protein for September 1999 include: $\mathrm{F}=131.31, \mathrm{df}=3,8, \mathrm{p}<0.0000$. ANOVA results for $\%$ crude protein for November 1999 include: $F=12.58, d f=5,12, p=0.0002$ 


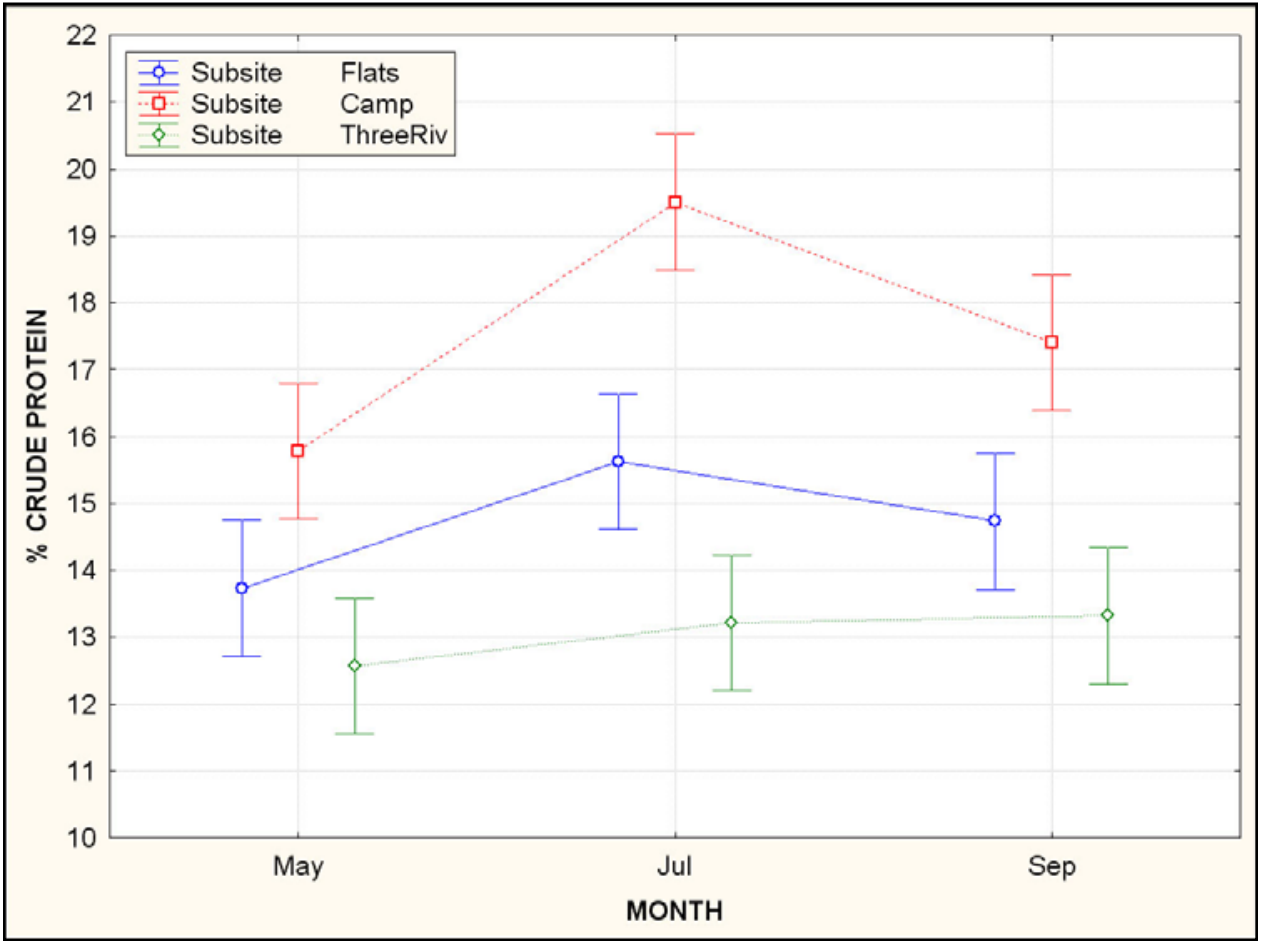

Figure 12. Percentage crude protein for all Lake Seminole sites sampled in 2000. Bars surrounding the means are the $95 \%$ confidence interval based on the ANOVA error terms. ANOVA results include: Site $-\mathrm{F}=60.33 \mathrm{df}=2$, 81, $p<0.0000$; Month $-F=12.50, d f=2,81, p=0.0000$; Site by Month interaction $-F=2.44, d f=4,81, p=0.054$

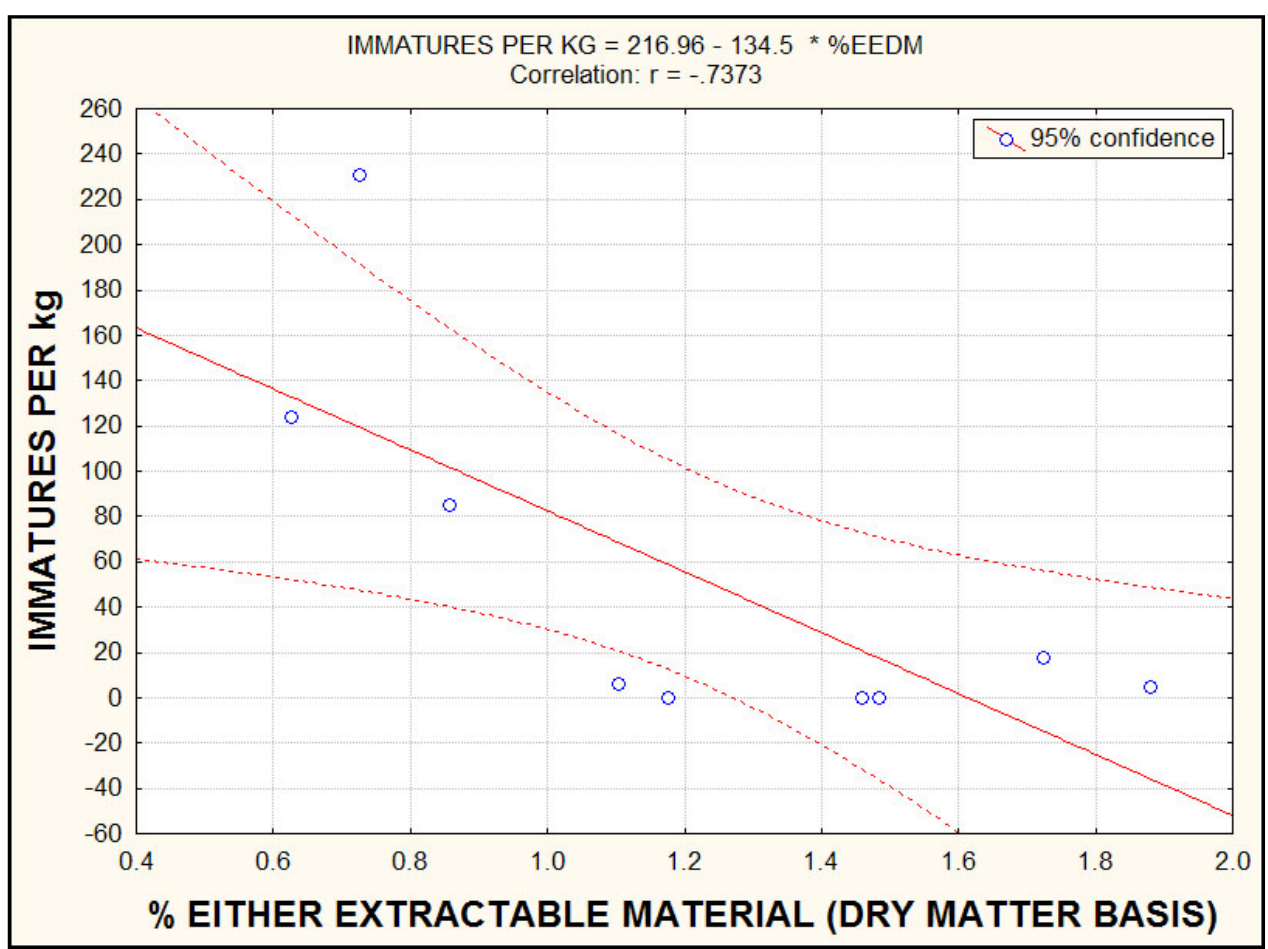

Figure 13. Relationship between mean immatures per $\mathrm{kg}$ and ether extractable compounds for sites samples on Lake Seminole during $2000(p<0.05$, $n=9, r=-0.7373$ ) 


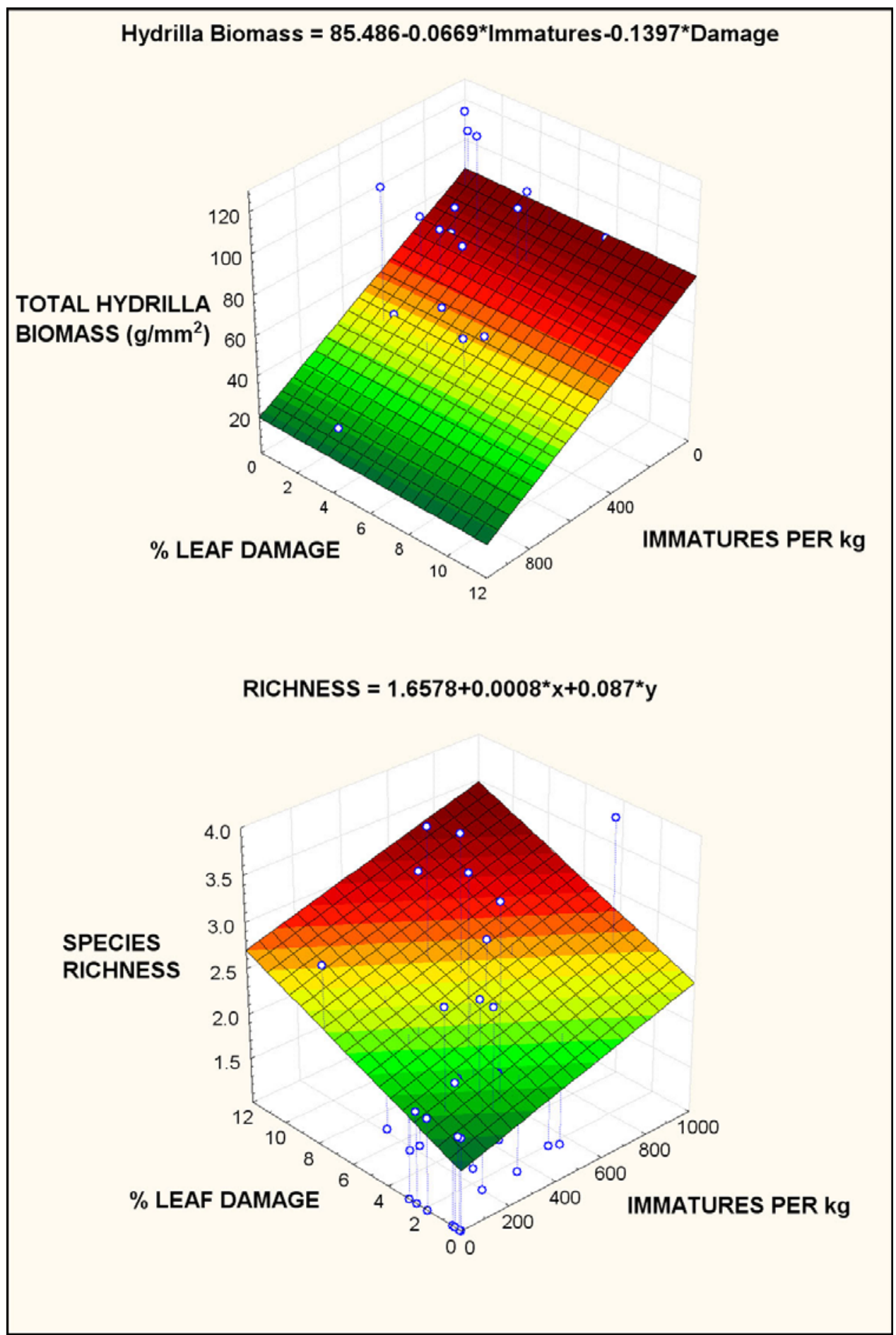

Figure 14. Statistical graphing technique using a linear (biomass) and quadratic model (species richness) examining the relationship between immatures per $\mathrm{kg}$, percent leaf damage, hydrilla biomass $(\mathrm{g} / \mathrm{mm} 2)$, and species richness for all Lake Seminole sites sampled during 2000. Note how lowest biomass occurs in samples with highest number of immatures and leaf damage. Species richness shows just the opposite trend with highest number of plant species occurring in those samples with highest number of immatures and damaged leaves 
It has often been observed at field sites that heavily damaged hydrilla stems are more brittle at the point of feeding and tend to break more easily (Grodowitz et al. 1999). It is assumed that such breakage is presumably opening the hydrilla canopy and allowing the native vegetation a competitive edge by increased light penetration and decreased productivity of hydrilla. We did observe strong, highly significant $(\mathrm{p}<0.05)$ correlations between the percentage of stems damaged and species richness (Figure 15). As stem damage increased, we observed significant increases in the number of plant species present in a given sample. In samples with 100 percent of the stems showing some sign of insect feeding, damage species richness increased almost 3 fold. Just the opposite occurred for hydrilla biomass (Figure 15). Biomass was decreased 2.5 fold in samples containing 100 percent of the stems damaged versus those with no signs of damage.

While evidence has been presented that indicates insect feeding has contributed to the declines in hydrilla observed on Lake Seminole during 1999 and 2000, other factors should not be discounted as playing a role. Discussions with various plant managers familiar with the Lake indicated that no abiotic or biotic factors occurred that could have triggered such declines in the hydrilla infestations and increases in the presence of other native species. However, several personnel reported that during this period excessive drought conditions caused decreases in lake levels that may have contributed to the hydrilla declines, but no evidence is available that supports the influence lower lake levels have on hydrilla infestations. Examination of Lake Seminole (Woodruff) midnight pool elevation data verifies the observation that decreases in pool elevation occurred during 1999 that were even more pronounced in 2000. For example, elevation during September 1999 was almost $23 \mathrm{~m}(75.8 \mathrm{ft})$, one of the lowest recorded for the last 5 years (Figure 16). Similar elevations were noted for 2000. Such decreases may have contributed to the observed species assemblage changes with shallower water allowing for more light penetration and thereby the growth of a higher number of native plant species. However, similar decreases have occurred in past years with no obvious shifts in the hydrilla populations.

These data collected during 2000 indicate that changes in hydrilla biomass, species richness, and tuber numbers were related to depth. For example, highest biomass, lowest species richness, and highest number of tubers all occurred in deeper water (Figure 17). Some of these changes were quite extreme with over 5fold increases in hydrilla biomass in the deeper water with the deep-water plant community mainly composed of hydrilla. With the higher biomass in deeper water, tuber numbers were also increased. Hence, it appears that decreases in pool elevation may have contributed to the observed changes in plant community; i.e., from a hydrilla monoculture to a mixed plant assemblage. Interesting leaf hardness also exhibited depth relationships with higher leaf hardness values associated with samples collected from deeper water. 


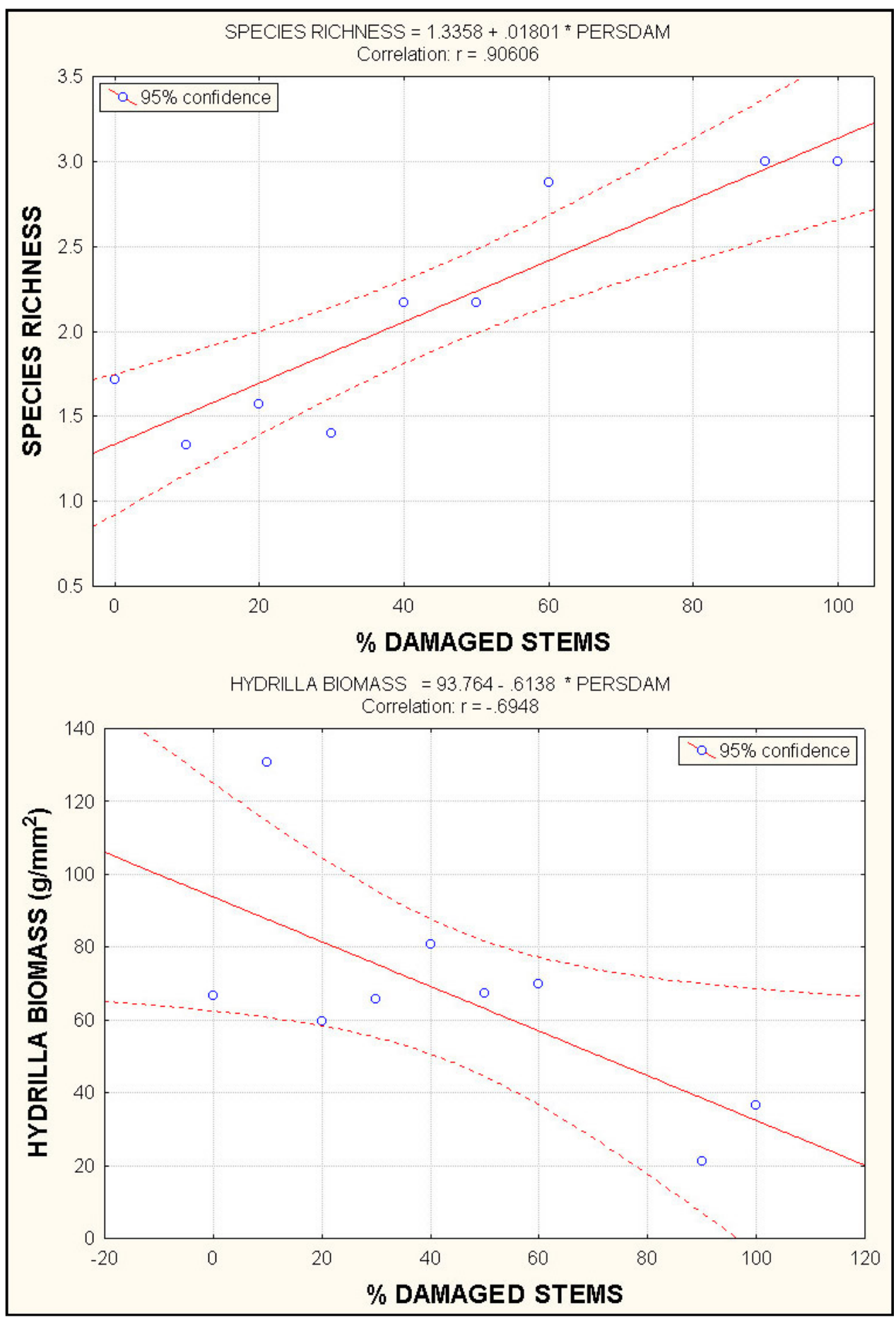

Figure 15. Relationship between the percentage of stems damaged to both species richness and hydrilla biomass. Note that highest species richness $(n=9, p<0.05, r=0.9061)$ and lowest hydrilla biomass $(\mathrm{n}=9, \mathrm{p}<0.05, \mathrm{r}=0.6948$ ) occur when the number of stems damaged by $H$. pakistanae larvae is high 


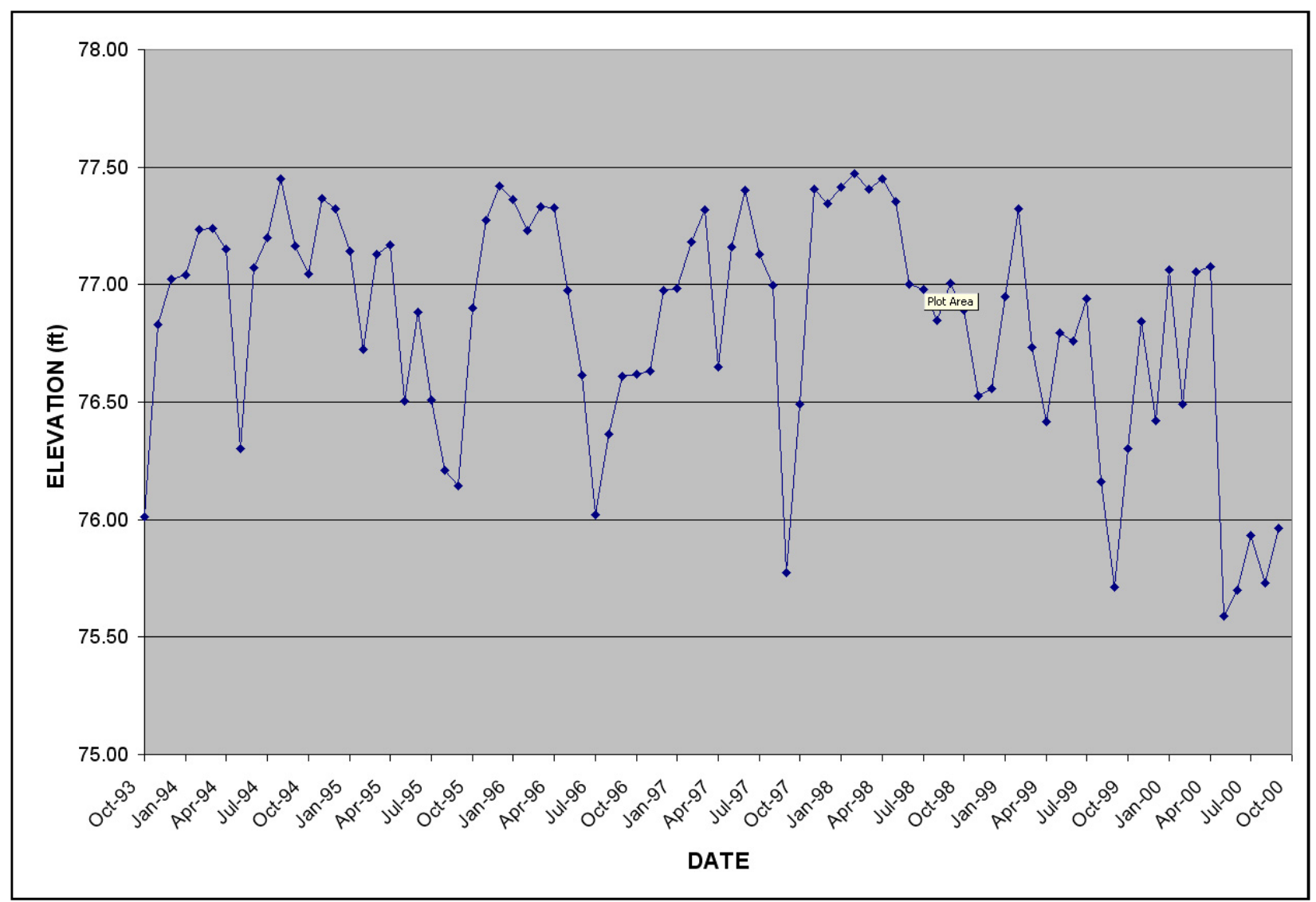

Figure 16. Lake Seminole midnight pool elevations from October 1993 through September 2000

But insect numbers and associated damage also changed with depth and may partially explain the differences in species richness and hydrilla biomass. Both immatures and percent leaf damage were over 2.5 fold higher on plants found in shallow water (Figure 18). This is not surprising since the hydrilla in shallower water should have surfaced earlier than in other deeper areas. Such surfaced hydrilla would have been more readily available to adult $H$. pakistanae egg deposition and, hence, higher larval feeding, thereby leading to decreases in photosynthesis and, ultimately, plant and propagule production (Doyle et al. 2002). 

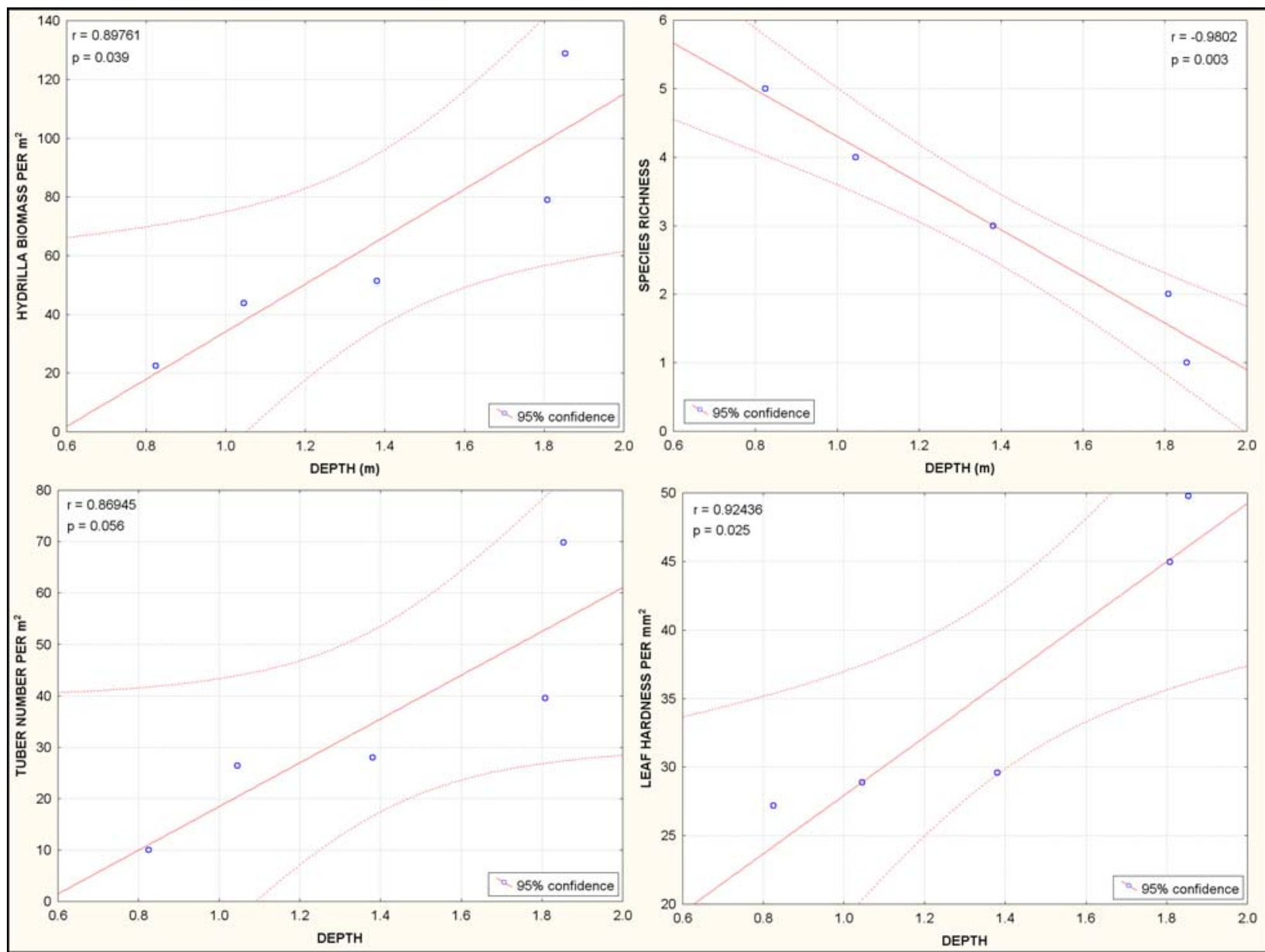

Figure 17. Correlations between depth and hydrilla biomass, species richness, tuber number per $\mathrm{m}^{2}$, and leaf hardness for means calculated on a species richness basis. All correlations are significant at the $p<0.05$ except for tuber number which is significant at $p=0.056$ level and $n=5$. The $r$ values and actual $p$-values are printed on each graph 

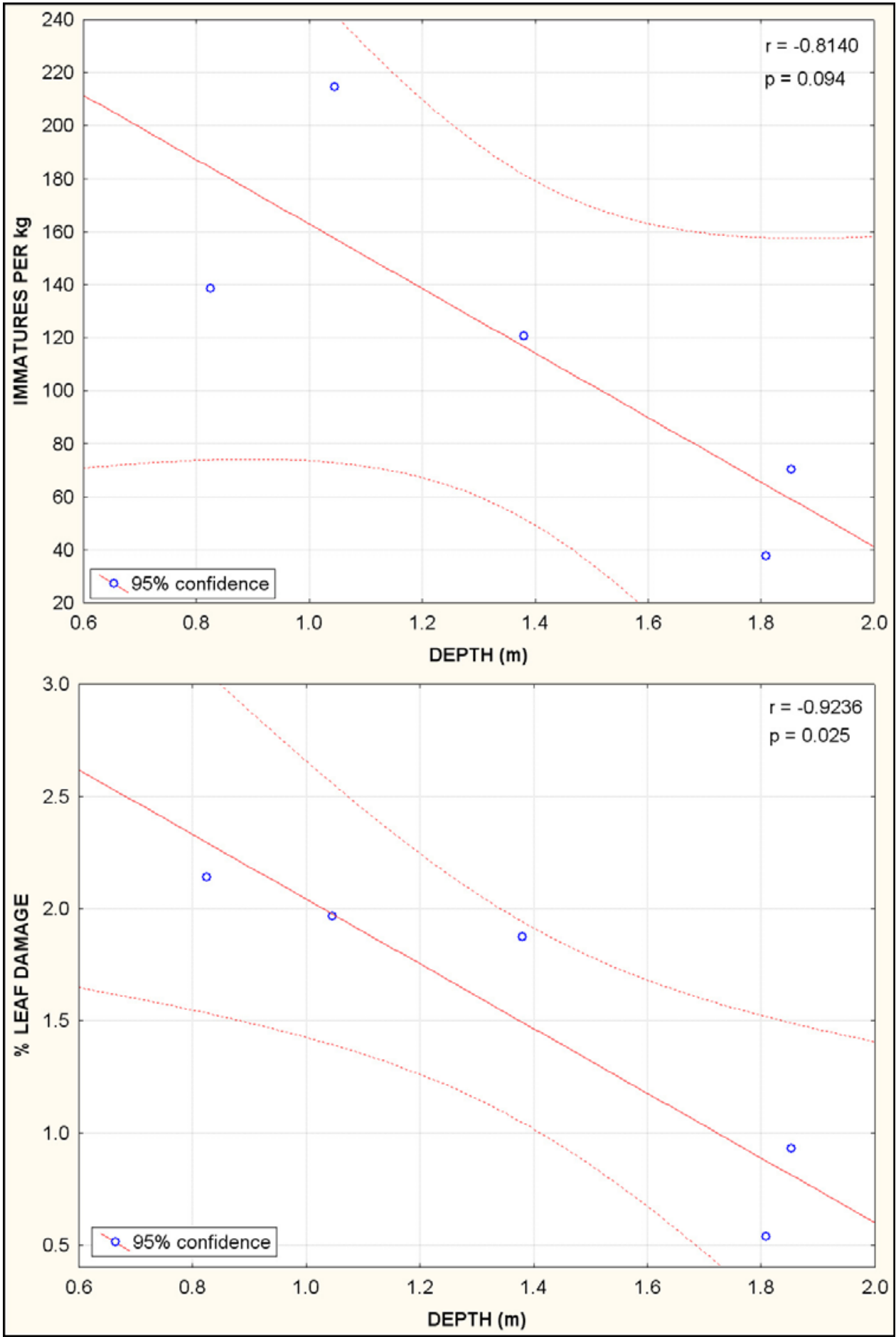

Figure 18. Influence of depth on both immatures per $\mathrm{kg}$ and percent damaged leaves for Lake Seminole sites sampled during 2000. Note that immatures and associated damage were significantly higher on hydrilla found in shallower water. Significance levels are $p=0.094$ for immatures versus depth and $p=0.025$ for percent damaged leaves versus depth 


\section{Summary}

In summary, there is a wide variety of information that indicates that the introduced leaf-mining fly, $H$. pakistanae, has had significant impact to Lake Seminole hydrilla. This is indicated by large increases in fly populations followed by decreases in tuber numbers and increases in species richness in 1999. While insect numbers were reduced in 2000, we still observed decreases in biomass and increases in species richness in those samples with higher number of immatures and/or associated feeding damage. While the evidence presented appears to indicate that the flies have played a major role in the hydrilla declines, other factors cannot be ruled out as contributing to the observed reductions. This includes such obvious changes as reductions in lake levels due to drought that may have increased light penetration in shallower areas, thus allowing for increased growth of natives. More likely, a complex of factors, including $H$. pakistanae feeding damage, contributed to the observed changes in hydrilla status. 


\section{References}

Baloch, G. M., and Sana-Ulah. (1974). "Insects and other organisms associated with Hydrilla verticillata (L. f.) L. C. (Hydrocharitaceae) in Pakistan." Proceedings of the 3rd International Symposium of Biological Control of Weeds. Montpellier, France, Misc. Publ. No. 8, Commonwealth Institute of Biological Control, Slough, UK, 61-66.

Bates, A. L., Decell, J. L., and Swor, C. T. (1991). "Joint agency plan, aquatic plant management on Guntersville Reservoir," Tennessee Valley Authority and U.S. Army Corps of Engineers.

Buckingham, G. R., Okrah, E. A., and Thomas, M. C. (1989). "Laboratory host range tests with Hydrellia pakistanae (Diptera: Ephydridae), an agent for biological control of Hydrilla verticillata (Hydrocharitaceae),"

Environmental Entomology 18 (1).

Center, T. D., Grodowitz, M. J., Cofrancesco, A. F., Jubinsky, G., Snoddy, E., and Freedman, J. E. (1997). "Establishment of Hydrellia pakistanae (Diptera: Ephydridae) for the biological control of the submersed aquatic plant Hydrilla verticillata (Hydrocharitaceae) in the Southeastern United States," Biological Control 8, 65-73.

Chapman, R. F. (1982). The insects: Structure and function. American Elsevier, New York, 919 pp.

Cofrancesco, A. F., and Pellessier, D. C. (1988). "Influence of herbicides on weevils used as biocontrol of waterhyacinth. Proceedings of the 22nd annual meeting Aquatic Plant Control Research Program," Miscellaneous Paper A88-5, U.S. Army Engineer Waterways Experiment Station, Vicksburg, MS.

Doyle, R. D., Grodowitz, M. J., Smart, R. M., and Owens, C. (2002). "Impact of herbivory by Hydrellia pakistanae (Diptera: Ephydridae) on growth and photosynthetic potential of Hydrilla verticillata," Biological Control 24, 221229.

. (2003). "Separate and interactive effects of competition and herbivory on the growth, expansion, and tuber formation of Hydrilla verticillata" (in preparation), J. of Ecology. 
Freedman, J. E., and Grodowitz, M. J. (2001). "Mass-rearing Hydrellia pakistanae deonier, a biological control agent of Hydrilla verticillata (L.F.) Royle, for release and establishment," ERDC/EL TR-01-24, U.S. Army Engineer Research and Development Center, Vicksburg, MS.

Gholson, A. K. (1984). "History of aquatic weeds in Lake Seminole," Aquatics 17.

Grodowitz, M. J., and Cofrancesco, A. F. (1990). "Effects of herbicides on Neochetina eichhorniae, a biocontrol agent of waterhyacinth. Proceedings of the 24th annual meeting Aquatic Plant Control Research Program," Miscellaneous Paper A-90-3, U.S. Army Engineer Waterways Experiment Station, Vicksburg, MS.

Grodowitz, M. J., and Pellessier, D. C. (1989). "Effects of chemical applications on the biological control agents of waterhyacinth. Proceedings of the 23rd annual meeting Aquatic Plant Control Research Program," Miscellaneous Paper A-89-1, U.S. Army Engineer Waterways Experiment Station, Vicksburg, MS.

Grodowitz, M. J., Freedman, J. E., Cofrancesco, A. F., and Center, T. D. (1999). "Status of Hydrellia spp. (Diptera: Ephydridae) release sites in Texas as of December 1998," Miscellaneous Paper A-99-1, U.S. Army Engineer Research and Development Center, Vicksburg, MS.

Grodowitz, M. J., and McFarland, D. G. (2002). "Developing methodologies to assess the influence of nutritional and physical characteristics of Hydrilla verticillata on its biological control agents," TN-APCRP-BC-05, U.S. Army Engineer Research and Development Center, Vicksburg, MS.

Grodowitz, M. J., and Snoddy, E. L. (1995). "New pond facility for aquatic plant biocontrol research," Aquatic Plant Control Research Program, Vol A-95-2, U.S. Army Engineer Waterways Experiment Station, Vicksburg, MS.

Haag, K. H. (1986a). "Effective control of waterhyacinth using Neochetina and limited herbicide application," Journal of Aquatic Plant Management, 24.

. (1986b). "Effects of herbicide application on mortality and dispersive behavior of waterhyacinth weevils, Neochetina eichhorniae and Neochetina bruchi (Coleoptera: Curculionidae)," Environmental Entomology, 15, 1192-1198.

U.S. Army Corps of Engineers. (1998). "Lake Seminole, FL-GA-AL Hydrilla Action Plan, U.S. Army Engineer District, Mobile, Inland Environmental Section," $208 \mathrm{pp}$.

U.S. Army Engineer Research and Development Center (ERDC). (1998). "Noxious and nuisance plant management information system, Version 4.0," M. Grodowitz, A. Cofrancesco, S. Whitaker, and L. Jeffers, ed. (CD-ROM), Vicksburg, MS. 
Van, T. K., Wheeler, G. S., and Center, T. D. (1998). "Competitive interactions between Hydrilla (Hydrilla verticillata) and Vallisneria (Vallisneria americana) as influenced by insect herbivory," Biological Control 11, 185192.

Wheeler, G. S., and Center, T. D. (1996). "The influence of hydrilla leaf quality on larval growth and development for the biological control agent Hydrellia pakistanae (Diptera: Ephydridae)," Biological Control 7, 1-9.

. (2001). "Impact of the biological control agent Hydrellia pakistanae (Diptera: Ephydridae) on the submersed aquatic weed Hydrilla verticillata (Hydrocharitaceae)," Biol. Control 21, 168-181. 


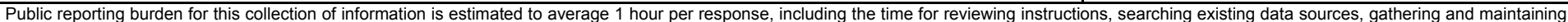

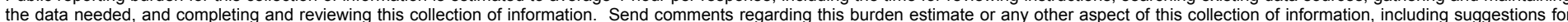

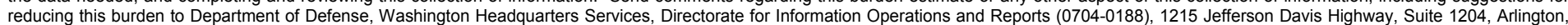

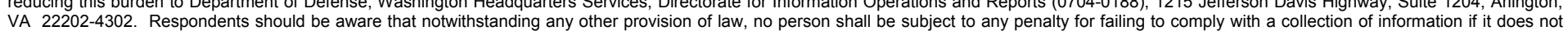
VA 22202-4302. Respondents should be aware that notwithstanding any other provision of law, no person shall be sube
display a currently valid OMB control number. PLEASE DO NOT RETURN YOUR FORM TO THE ABOVE ADDRESS.

\begin{tabular}{l|c}
$\begin{array}{l}\text { 1. REPORT DATE (DD-MM-YYYY) } \\
\text { September } 2003\end{array}$ & $\begin{array}{c}\text { 2. REPORT TYPE } \\
\text { Final report }\end{array}$ \\
\hline
\end{tabular}

\section{TITLE AND SUBTITLE}

Possible Impact of Lake Seminole Hydrilla by the Introduced Leaf-Mining Fly Hydrellia pakistanae

\section{DATES COVERED (From - To)}

\section{5a. CONTRACT NUMBER}

5b. GRANT NUMBER

5c. PROGRAM ELEMENT NUMBER

5d. PROJECT NUMBER

\section{AUTHOR(S)}

Michael J. Grodowitz, Alfred F. Cofrancesco, Robert M. Stewart, John Madsen, Don Morgan

\section{5e. TASK NUMBER}

\section{5f. WORK UNIT NUMBER}

8. PERFORMING ORGANIZATION REPORT NUMBER

ERDC/EL TR-03-18

U.S. Army Engineer Research and Development Center, Environmental Laboratory, 3909 Halls Ferry Road, Vicksburg, MS 39180-6199;

U.S. Army Engineer District, Mobile, Lake Seminole Project Office,

Chattahoochee, FL 32324

\section{SPONSORING / MONITORING AGENCY NAME(S) AND ADDRESS(ES)}

Headquarters, U.S. Army Corps of Engineers

Aquatic Plant Control Research Program

Washington, DC 20314-1000
10. SPONSOR/MONITOR'S ACRONYM(S)

11. SPONSOR/MONITOR'S REPORT NUMBER(S)

\section{DISTRIBUTION / AVAILABILITY STATEMENT}

Approved for public release; distribution is unlimited.

\section{SUPPLEMENTARY NOTES}

\section{ABSTRACT}

Hydrellia pakistanae, a biological control agent of hydrilla, was first introduced into Lake Seminole in 1990. Impact by this species remained low until 1998 when large numbers of individuals and associated impact, as well as increases in native plant diversity, were observed in several locations. In 1999, large-scale reductions in hydrilla were observed throughout many areas of the lake. These changes were correlated with changes in insect numbers where large increases in fly populations were correlated with decreases in tuber numbers and increases in species richness. While insect numbers were reduced in 2000, significant decreases in biomass and increases in native plant diversity were observed when numbers of immatures and/or feeding damage were high. While the evidence presented herein indicates that the flies played a major role in the hydrilla decline on Lake Seminole, other factors may have contributed to the observed reductions. This includes such obvious changes as decreases in lake levels brought on by drought that may have increased light penetration in shallower areas, thus allowing for increased growth of natives. More likely, a complex of factors, including H. pakistanae feeding damage, contributed to the observed changes in hydrilla status on Lake Seminole.

\section{SUBJECT TERMS}

Aquatic plant

Biological control

16. SECURITY CLASSIFICATION OF:

a. REPORT

UNCLASSIFIED

b. ABSTRACT
UNCLASSIFIED

Hydrellia

Insect herbivory

\begin{tabular}{|l|c|}
\hline $\begin{array}{l}\text { 17. LIMITATION } \\
\text { OF ABSTRACT }\end{array}$ & $\begin{array}{c}\text { 18. NUMBER } \\
\text { OF PAGES }\end{array}$ \\
\cline { 3 - 3 } & 35 \\
\hline
\end{tabular}

19a. NAME OF RESPONSIBLE PERSON

19b. TELEPHONE NUMBER (include area code) 